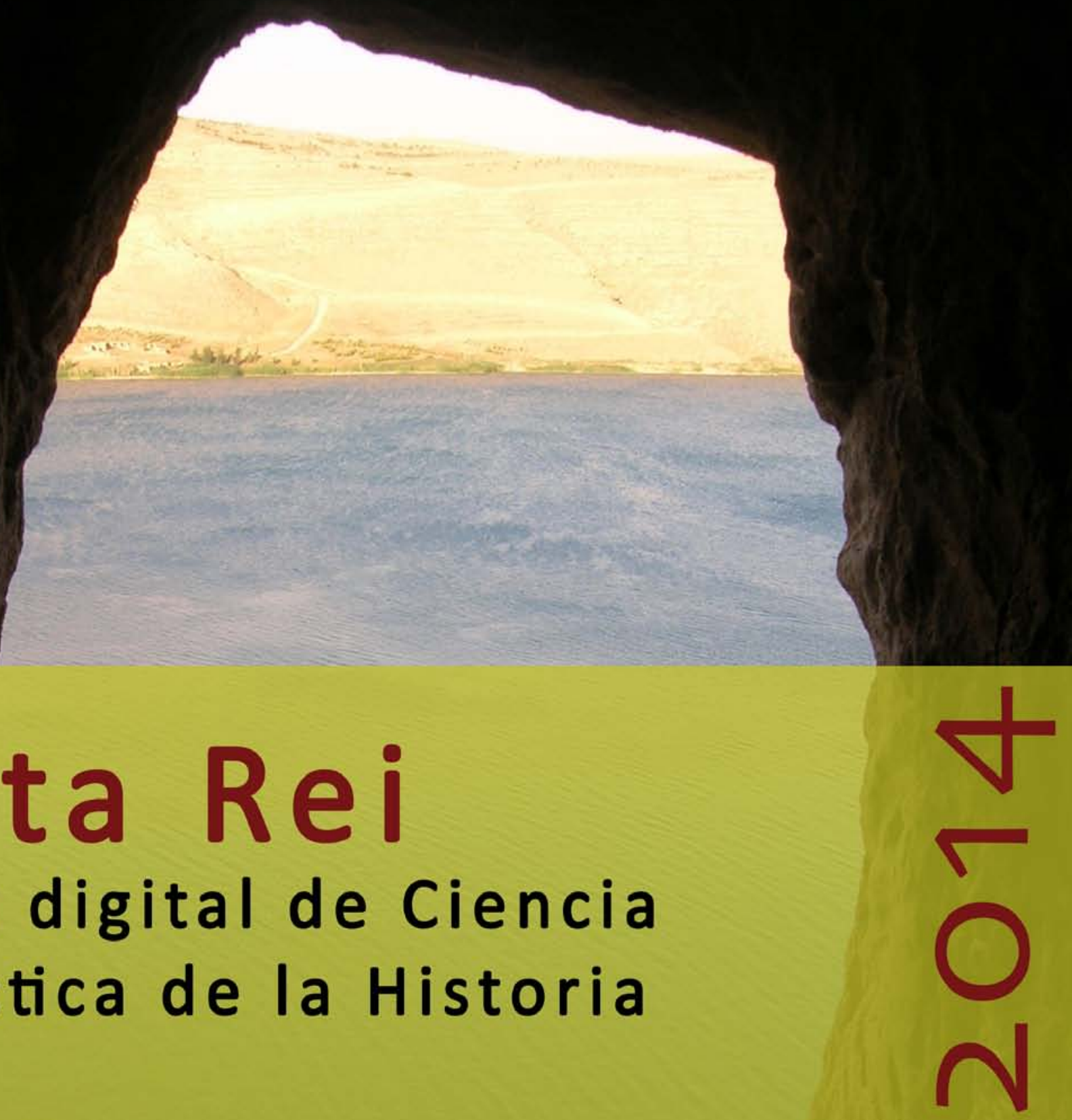





\section{Panta

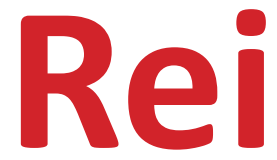 \\ Revista Digital de Ciencia \\ y Didáctica de la Historia}

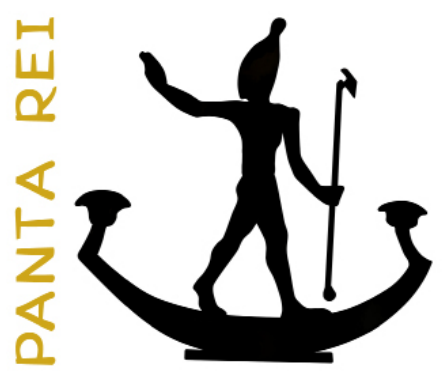

2014

Revista anual

Fecha de inicio: 1995

Revista Panta Rei. pantarei@um.es

\section{Edita:}

Centro de Estudios del Próximo Oriente y la

Antigüedad Tardía - CEPOAT

Edificio Universitario Saavedra Fajardo.

Universidad de Murcia

C/ Actor Isidoro Máiquez, 9

30007 - MURCIA - ESPAÑA

Teléfono: (+34) 868883890

cepoat@um.es

Web: www.um.es/cepoat/pantarei

Edición 2014

ISSNe: 2386-8864

ISSN: $1136-2464$

Depósito legal: MU-966-1995
cepoAt

UNIVERSIDAD DE MURCIA centro de estudios del próximo oriente y la antigüedad tardia

En Portada: Río Éufrates desde un eremitorio cristiano primitivo (Fotografía de Alejandro Egea).

Responsables de los textos:

Sus autores.

Responsable de la presente edición: Consejo Editorial Panta Rei. 


\section{CONSEJO DE REDACCIÓN}

\section{Coordinador editorial}

Egea Vivancos, Alejandro

[Didáctica de las Ciencias Sociales, UMU]

\section{Editores}

Botí Hernández, Juan Jesús

[CEPOAT, UMU]

Sáez Giménez, David Omar [CEPOAT, UMU]

\section{Secretaria}

Arias Ferrer, Laura

[Didáctica de las Ciencias Sociales, UMU]

\section{Responsable informático}

Martínez García, José Javier

[CEPOAT, UMU]

\section{Traducción y corrección lingüística}

Martínez Martínez, Cristina

[Sociedad Española de Lenguas Modernas]

\section{CONSEJO ASESOR}

Albero Muñoz, M. ${ }^{a}$ del Mar [H. ${ }^{a}$ del Arte, UMU]

Cobacho López, Ángel

[Derecho, UMU]

Egea Bruno, Pedro M. ${ }^{a}$

[Historia Contemporánea, UMU]

García Atienzar, Gabriel

[Prehistoria, UA]

González Monfort, Neus

[Didáctica de las Ciencias Sociales, UAB]

Haber Uriarte, María

[Prehistoria, UMU]

Irigoyen López, Antonio

[Historia Moderna, UMU]

Mahony, Simon

[Digital Humanities, UCL, Reino Unido]

Marsilla de Pascual, Francisco Reyes

[Técnicas historiográficas, UMU]

Miralles Maldonado, José Carlos

[Filología Clásica, UMU]

Molina Gómez, José Antonio

[Historia Antigua, UMU]

Noguera Celdrán, José Miguel

[Arqueología, UMU]

Pérez Molina, Miguel Emilio

[Filología Clásica, UMU]

Prados Martínez, Fernando

[Arqueología, UA]

Sánchez Ibáñez, Raquel

[Didáctica de las Ciencias Sociales, UMU]

Sancho Gómez, Miguel Pablo

[Educación, UCAM]

Vilar García, María José

[Historia Contemporánea, UMU] 
Presentación

Todo fluye. Renovarse y crecer

Alejandro Egea Vivancos, Laura Arias Ferrer, Juan Jesús Botí Hernández y David Omar Sáez Giménez

Artículos

La sociedad hiperbórea: ¿utopía o mito? Reflexiones acerca de la naturaleza y significado del relato hiperbóreo.

José Ángel Castillo Lozano.

Aproximación a la figura de una matrona romana culta y poderosa. El caso de Julia Domna.

Consuelo Isabel Caravaca Guerrero.

¡Arrasar la Vendée! Guerra Civil y Columnas Infernales en pleno corazón de la Revolución Francesa.

Benjamín Cutillas Victoria.....

Arte y expresión en el pensamiento de E. H. Gombrich.

Patricia Castiñeyra Fernández.

Odiseo a través de la parodia. Desmitificación e ironía de una Ítaca nostálgica en Prometeo de Pérez de Ayala y ¿Por qué corres, Ulises? de Gala.

Carmen María López López.

Análisis de la actividad didáctica del Museo de Arte Ibérico El Cigarralejo (Mula, Murcia).

Julio García Toral......

La Transición española en $4 .^{\circ}$ ESO. Un estudio de caso de los significados.

Borja Santiago Arnoso.

Entrevista

Entrevista al profesor D. Michael Walker.

Consuelo Isabel Caravaca Guerrero.

Reseñas

II Congreso de la Asociación Internacional de Investigación para la Educación de la Historia y las Ciencias Sociales.

Elvira Barriga y Rodrigo Salazar.

I Congreso de Jóvenes Investigadores del Mundo Antiguo de la Universidad de Murcia.

Pedro David Conesa Navarro

II Congreso Internacional de Educación Patrimonial.

Tània Martínez Gil.....

Ruiz-Gálvez Pliego, M. (2013). Con el fenicio en los talones. Los inicios de la Edad del Hierro en la cuenca del Mediterráneo. Barcelona: Editorial Bellaterra. 377 págs.

Celso Sánchez Mondéjar..

Normas de publicación/Publishing rules 



\title{
Odiseo a través de la parodia. Desmitificación e ironía de una Ítaca nostálgica en Prometeo de Pérez de Ayala y ¿Por qué corres, Ulises? de Gala
}

\author{
Odysseus through parody. Demythologization and irony of a nostalgic \\ Ithaca in Prometeo by Pérez de Ayala and ¿Por qué corres, Ulises? by \\ Gala
}

Recibido: 29/05/2014

Aceptado: 06/10/2014

Carmen María López López

Universidad de Murcia

\begin{abstract}
Para citar este artículo: López López, C. M. (2014). Odiseo a través de la parodia. Desmitificación e ironía de una Ítaca nostálgica en Prometeo de Pérez de Ayala y ¿Por qué corres, Ulises? de Gala. Panta Rei. Revista Digital de Ciencia y Didáctica de la Historia, 71-96.

ISSNe: 2386-8864

DOI: http://dx.doi.org/10.6018/pantarei/2014/6
\end{abstract}

\section{Resumen}

El objetivo de este artículo es proponer un estudio crítico-comparado a partir de las variaciones del modelo épico en dos obras de la literatura española del siglo XX: Prometeo de Ramón Pérez de Ayala y ¿Por qué corres, Ulises? de Antonio Gala. Para ello, se trazará una perspectiva histórica de acuerdo con algunos de los episodios homéricos insertos en la Odisea: la estancia del héroe con Nausica en la tierra de los feacios, con la ninfa Calipso en Ogigia, con la maga Circe en la isla de Eea, en la tierra de los Lotófagos, la Nekuia o descenso al Hades y el reencuentro con Penélope. Por último, este artículo pretende analizar el sentido de la risa desde la tradición, con la finalidad de atender a la reinterpretación del mito como parodia e ironía respecto del relato homérico.

\section{Palabras clave}

Homero, Parodia, Mito, Literatura, Historia.

\begin{abstract}
The aim of this article is to propose a critical and comparative study beginning from the epic model variations on the Spanish Literature from the twentieth century: Prometeo by Ramón Pérez de Ayala and ¿Por qué corres, Ulises? by Antonio Gala. To this purpose, a historic perspective will be designed, according to some Homeric episodes inside of the Odisea: the stay of the hero with Nausicaa in the phaeacians' land, with the nymph Calypso in Ogygia, with the magician Circe in the Eea's island, in the Lotofagi's land, the Nekuia and the re-encounter with Penelope. To conclude, this article pretends to analyze the sense of the laugh from the tradition, to deal with the reinterpretation of the myth as a parody and an irony regarding the Homeric narration.
\end{abstract}

\section{Key Words}

Homero, Myth, Parody, Literature, History. 


\section{Marco teórico y metodología}

La historia de Odiseo se ha convertido en epítome del viaje hasta tal punto que, a través de los siglos, ha adquirido carta de naturaleza para reformularse de acuerdo con las inquietudes histórico-culturales y sociales de la época en que aflora su condición mítica. A este respecto, Hans Blumenberg en su Trabajo sobre el mito (2003) aludió a la doble condición icónica presente en el mito: la permanencia de una serie de motivos arraigados desde la tradición mítica y la reinterpretación de los mitos según condicionamientos sociales, históricos y culturales (Morano, 1982; Lasso de la Vega, 1989), pues una materia "tiene sus propias leyes y al mismo tiempo lleva implícito el recuerdo de la cultura que la impregna (el eco de la intertextualidad)" (Eco, 2009, pp. 740-741). Así pues, los mitos se establecen como historias con un sólido núcleo narrativo, al mismo tiempo que con una ingente capacidad de variación - lo que en el ámbito de la música a partir de Bach se denominó "variaciones sobre un tema"- . Se distinguen, así, de los textos sagrados en el hecho de su variabilidad: "NAUSICA. - [...] Tú eres un mito, Ulises. No estás hecho para que te pregunten cada día qué quieres de segundo plato. Has nacido para águila y aquí te hubieran rebajado a gallina clueca" (Gala, 1975, p. 85).

Para este propósito de reinterpretación del mito, la obra de referencia fundamental es la Odisea de Homero, a partir de un ejercicio de hipertextualidad (Genette, 1989, p. 14), en virtud del cual las obras de Ayala y Gala actúan como texto B (hipertexto) en relación con un texto anterior o texto base A (hipotexto), en este caso, la epopeya homérica. Por lo tanto, la justificación de este estudio se sustenta sobre el pilar de una relación de copresencia entre los textos analizados, es decir, a través de los distintos tipos de intertextualidad subrayados por Genette (ibídem, p. 10), entre ellos la cita o la alusión como mecanismos de influencia inherentes a la lectura literaria. De esta mirada y forma de comprensión de la literatura, Prometeo y ¿Por qué corres, Ulises? se configuran como un palimpsesto sobre el que la pátina del tiempo ha ido reescribiendo su propia tradición a la manera de un pergamino reutilizado.

Si ¿Por qué corres, Ulises? es una pieza teatral donde prevalece la caracterización de los personajes, Prometeo se dispone en términos genéricos como novela poemática ${ }^{1}$, por lo que aflora en ella la doble condición de novela y poema. Frente al desarrollo de los acontecimientos a que da lugar la formalización artística de la novela —aquella hermosa idea de Barthes (1968) denominaba "el efecto de realidad"-, en el poema el mito emerge como una idea irradiada en un instante concreto. De este modo, se pone de relieve la adaptabilidad de las figuras míticas a los distintos géneros y a las distintas épocas (Stanford, 2013).

Una vez establecido el marco de reformulación del mito en Ayala y Gala, se analizarán los episodios homéricos evocados en ambas obras, entre ellos la estancia del héroe con Nausica en la tierra de los feacios, con la ninfa Calipso en Ogigia, con la maga Circe en la isla de Eea, en la tierra de los Lotófagos, la Nekuia o descenso al Hades y el reencuentro con Penélope. Se reservará un espacio a la profundización en la huella de procedimientos y recursos de la narración homérica: descripción o écfrasis, oralidad y escritura, mimesis y diegesis y juegos en el orden temporal (analepsis y prolepsis). De este modo, podremos situarnos en el estadio de la parodia en el siglo XX, a partir de las ideas de Bajtin sobre la estilización o marcas de estilo (estilemas), para acercarnos al sentido de la risa desde la tradición.

Puesto que las obras de Ayala y Gala implican una lectura en clave paródica e irónica, a la hora de contextualizar este estudio, habría que citar el referente cultural de Luciano de Samósata, quien en sus Relatos verídicos realiza una versión irónica del relato de viajes (Lens Tuero y Campos

1 El sintagma novela poemática incide en la ruptura de los límites genéricos desde el Romanticismo. Así pues, el tema de Ulises como arquetipo literario o el motivo del periplo se irán repitiendo junto a otras reformulaciones temáticas y formales: las aventuras amorosas, la astucia del héroe o la fidelidad/infidelidad de Penélope, como en La tejedora de sueños de Buero Vallejo. 
Daroca, 2000). Desde esta perspectiva, Ulises se erige no ya como figura modélica del relato de viajes heroicos, sino como antimodelo tildado de charlatán, tal como advierte Luciano de Samosata:

Su guía y maestro de semejante charlatanería es el Ulises de Homero que disertó ante la corte de Alcínoo acerca de vientos en esclavitud y de hombres de un solo ojo, caníbales y salvajes; $y$ además de animales de múltiples cabezas y las transformaciones de sus compañeros a causa de los elixires: con múltiples relatos de este género dejó maravilladas a gentes tan simples como los feacios.

(Luciano de Samosata, 1996, pp. 13-14)

La pátina irónica tamizada en Prometeo y ¿Por qué corres Ulises? es deudora de un sentido del viaje como desmitificación y descreimiento (García Gual, 1997), imperante ya en el relato de Luciano. Sin embargo, es lícito diferenciar los contextos de escritura de ambas obras, alentadas por una motivación y clave interpretativa distintas.

\section{La reformulación del mito. Motivaciones histórico-culturales en la escritura de Prometeo y ¿Por qué corres, Ulises?}

Prometeo de Ramón Pérez de Ayala es una novela poemática que cruza dos mitos fundamentales en la historia de nuestra tradición literaria: el mito de Ulises y el de Prometeo ${ }^{2}$, con el que el autor intitula la obra. El tema de Odiseo (Brommer, 1983; Boitani, 1992; Perpinyá, 2008) se constituye como el del peregrino errabundo que abandona su patria; de otro lado, el mito de Prometeo (Trousson, 1976) responde al del iracundo Titán al que Zeus castigó por la osadía de hurtar el fuego a los dioses. Pero si bien ambos mitos actúan como sustrato del que se sirve Pérez de Ayala, desde el principio apreciamos atisbos de modernidad, cifrados en el moderno Odiseo o la moderna Nausikaa, tal como aparecen en la Rapsodia a manera de prólogo. Por tanto, se vislumbra una reformulación o reinterpretación del mito originario atribuido al primer poeta de Occidente: Homero (Curtius, 1995).

Junto con Luz de domingo y La caída de los limones, Prometeo configura la tríada novelística que en 1916 Pérez de Ayala reunió en un mismo volumen bajo el subtítulo: Novelas poemáticas de la vida española. La prosa de Pérez de Ayala rompe con esa visión realista que abrazó buena parte del siglo XX, para gustar de una verdad poética más honda. Si el hombre no puede vivir sin cortapisas pues su vida semeja al periplo de Odiseo, es de justicia que contemplemos el tema de Ulises al calor del mito ${ }^{3}$. En Prometeo el autor devuelve al lector de los siglos XX y XXI toda la verdad de su tiempo, de la España anunciada por el genio de Larra, y que tanto le dolió a Unamuno y otros escritores noventayochistas.

Para encontrarnos con la figura de Ulises en la literatura del siglo $X X$, hay que esperar a la Generación del 98 (Calvo, 1991). Así pues, el Ulises de Ayala se erige como un perdedor cuya vida literaria adquiere carta de naturaleza simbólica, en una época de profundo pesimismo en la producción literaria del escritor, cuyo pensamiento entra en consonancia con la realidad española. El Ulises de Ayala personifica al Hombre de su época y a los propios regeneracionistas, elevando a categoría universal el sentido de la novela. Aflora, por lo tanto, la dialéctica entre el hombre de pensamiento y el hombre de acción ${ }^{4}$, si bien la felicidad está reservada al hombre de acción, al que le

2 El mito de Prometeo se relata en la Teogonía de Hesíodo como el robo del fuego olímpico a los dioses; por lo tanto, aflora como un acto de hybris por parte del Titán Prometeo, así como el continuo enfrentamiento técnica-ser humano.

3 En palabras de Antonio Gala (1975, p. 97) en el Epílogo a ¿Por qué corres Ulises?, "Cualquier odisea es el relato de un retorno - a la larga es igual retornar vencedor o vencido- y de una desanimada espera".

4 Para relacionar los contextos de la acción humana en Homero y Pérez de Ayala, sobre la filosofía de la acción Rodríguez Adrados (1962) sostiene que la afirmación de necesidad en la medida y autolimitación en 
precede el hombre de pensamiento que diseña la acción, hacia un nuevo Prometeo o superhombre nietzscheano. En palabras de Calvo (1991, p. 358), "Ios españoles tienen ansias de infinito, aspiran a ser como Dios, pero mientras fracasan en el intento de conseguir este ideal, fracasan también en el de convertirse en hombres". Así pues, Prometeo se alza como metonimia del hombre español de principios de siglo:

El hombre moderno arreligioso asume una nueva situación existencial: se reconoce como único sujeto y agente de la historia, y rechaza toda llamada a la trascendencia. Dicho de otro modo: no acepta ningún modelo de humanidad fuera de la condición humana, tal como se puede descubrir en las diversas situaciones históricas. El hombre se hace a sí mismo y no llega a hacerse completamente más que en la medida en que se desacraliza y desacraliza al mundo. Lo sacro es el obstáculo por excelencia que se opone a la libertad. No llegará a ser el mismo hasta el momento en que se desmitifique radicalmente. No será verdaderamente libre hasta no haber dado muerte al último dios.

(Eliade, 1998, p. 148)

En definitiva, el Ulises de Ayala constituye un pretexto para mostrar la visión profundamente pesimista que caracterizó a la Generación del 98 en una España atrasada y macabra donde era difícil buscar una salida. El protagonista intenta encontrar un refugio en Prometeo, trasunto del superhombre nietzscheano, si bien finalmente fracasa. Tras el orden roto y la caída del héroe, queda el consuelo metafísico ${ }^{5}$ del que habló Nietzsche en El nacimiento de la tragedia (Rodríguez Adrados, 1962). Abundan, por tanto, innúmeras referencias filosóficas: el influjo de Schopenhauer, Nietzsche y Unamuno, que ya en 1902 había escrito Amor y Pedagogía, en la que aflora una tesis similar a la del Prometeo de Ayala (Calvo, 1991).

Por su parte, según confiesa Antonio Gala al inicio de ¿Por qué corres, Ulises? (1975) y ha estudiado García Romero (1983, p. 289), el motivo de arranque en la escritura de esta obra giró en torno al hecho de retratar al Ulises de la posguerra, al Ulises del 75 y la Nausica del 75 , así como poner en solfa al "conservador puro" (Gala, 1975, p. 6). Según escribe Gala:

Todos somos Ulises o Nausica o Penélope. Todos hemos sufrido las consecuencias de una lejana guerra, cuyas causas se nos han olvidado. Todos esperábamos llegar alguna vez donde nunca llegamos. Todos hemos perdido demasiado tiempo y culpado de nuestras tonterías al destino y los dioses.

(Gala, 1975, p. 97)

Entre los contextos de escritura de las dos obras objeto de análisis median unos cincuenta años y, en ese lapso temporal de medio siglo, operan transformaciones en sentido hermenéutico. En palabras de Gala, su Ulises 75 traiciona al Ulises clásico en la manera de concebir al personaje. $\mathrm{Si}$ en la tradición homérica el héroe se muestra como modelo o paradigma de la fidelidad, en los tiempos de la España de posguerra parece trasnochado considerar al personaje un buen marido, luego de haber tardado veinte años en regresar a su patria (Gala, 1975; Navarro, 1993). Para la

la acción humana ya existían antes de la literatura en la religión y en el pensamiento de la época arcaica. A este respecto, las máximas de los Siete Sabios aconsejaban que lo mejor es la medida, nada en exceso, el "conócete a ti mismo y, contigo, tus límites", tal como aparece grabado en el templo de Delfos. Sin embargo, frente a la limitación y la mesura, se insiste en la autoafirmación del hombre mediante la acción. Frente a la acción, en la producción moderna encontramos a un héroe "pasivo y cobarde" sobre el que se acumulan la sinrazón y la falta de sentido ante las desgracias humanas (ibídem, p. 35).

5 "El trasfondo metafísico de la tragedia griega ha desaparecido irremediablemente. Pero en la otra mitad la audacia, el valor y, también, el error y la limitación del hombre continúan vivos como fuente de poesía y verdad" (Rodríguez Adrados, 1962, p. 35). 
Nausica 75, el Ulises 75 es burgués cursi y anticuado que guarda fidelidad. Se produce una tensión entre lo que Ulises 75 espera de las mujeres y lo que en realidad las mujeres le ofrecen. En el caso de Nausica 75, lo humilla. En cuanto al personaje de Penélope 75, Ulises espera de ella que sea una "doñaconcha de derechas de toda la vida" (Gala, 1975, p. 8), tildada con los atributos de mujer fiel e inmóvil.

El punto de intersección entre estas dos obras tan disímiles en su sentido se cifra en la Odisea, que actúa como texto base en el que se relatan las aventuras del héroe hasta su llegada a Ítaca. Las obras que se analizan requieren, por tanto, de un ejercicio de intertextualidad (Genette, 1989). Prometeo se convierte casi en un "mosaico de citas" (Kristeva, 1997, p. 3), o en una "cámara de ecos" (Barthes, 1997, p. 87). El texto literario deviene, de este modo, caja de resonancia de diversos discursos.

Sin embargo, las motivaciones del viaje son sustancialmente distintas en las obras de Homero, Pérez de Ayala y Gala. En la epopeya homérica, el héroe declara desde el principio el disgusto por su condición errante que lo aleja de su añorada patria, en virtud de la cólera de un dios que marca el carácter forzado de su viaje (Gómez Espelosín, 2000). Sin embargo, el Odiseo de Ayala es hijo de español e italiana. Nace en Florencia y su viaje se impone como súbita iluminación, por lo que decide regresar a su verdadera patria: España, donde acaecen todas sus aventuras. El primer lugar donde recalará es Sevilla, la tierra de los Lotófagos. Emprende su peregrinación por toda España: al Sur le falta fuerza; en el Levante encuentra la gracia y en el Norte la astucia (Calvo, 1991). Se dirige al centro donde no encuentra más que una ciudad muerta (el Hades). Consulta a Tiresias, un sabio que tenía cara de búho (Unamuno) que le dice que ya no volverá a ser un hombre, sino el recuerdo de un hombre. Huye de Madrid, episodio que el protagonista asocia con la aventura de las vacas del Sol (Helios). Esos vaivenes madrileños se simbolizan también en el peligro de Escila y Caribdis.

La estancia de Odiseo en la tierra de los Feacios se fundamenta como escala final un viaje que lo conduce a su retorno al mundo real (Rogers, 1984; Cazorla, 1986). Así pues, su permanencia junto a Nausica constituye un estadio intermedio entre el universo mítico-fabuloso en que se han desarrollado las andanzas del héroe, y el regreso a la realidad prosaica y cotidiana simbolizada en Ítaca (Gómez Espelosín, 2000). La geografía mítica pierde su condición fabulosa en las obras de Pérez de Ayala y Gala. El espacio en que se desenvuelve el periplo de Odiseo en la obra de Gala es una España decadentista donde el referente de Ítaca como meta se ha perdido (Robertson, 1990). En la Odisea, tanto la intervención divina como la firme voluntad de retorno por parte del héroe actúan como fuerzas motrices en la consecución del regreso (nostos). Sin embargo, "las exigencias del guión hacen que el Odiseo de Ayala no tenga Penélope y que su Ítaca definitiva coincida con Feacia. El meollo de la obra será su casamiento con Nausica y el fruto del mismo" (Calvo, 1991, p. 355).

Si "las islas representaban dentro de la mentalidad griega el escenario adecuado para albergar toda clase de maravillas" (Gómez Espelosín, 2000, p. 75), ese aislamiento natural desaparece en la novela de Ayala, donde los condicionamientos sociales impiden al personaje alzarse como superhombre nietzscheano. Además, el periplo odiseico puede interpretarse como un viaje de carácter iniciático en el que el héroe ha de someterse a pruebas cuya superación culminaría en un renacimiento como ser humano. La diferencia entre el poema homérico y la novela corta de Ayala estriba en que en esta última el héroe no supera la prueba. El sentido simbólico del viaje concluye con el fracaso en la obra de Gala (Moya, 2009), en razón del impedimento de Ulises de alcanzar la imagen soñada de una Penélope ${ }^{6}$ inmóvil y virtuosa.

6 Contrasta esta Penélope con el modelo de fidelidad conyugal que simboliza la Penélope de Homero. Pueden serconsultadas, a este respecto, los siguientes estudios que perfilan la caracterización de esta figura desde la literatura homérica (Felson-Rubin, 1994; García Romero, 1997; Katz, 1991; López López, 2000; Mactoux, 1975). 


\section{La evocación de episodios homéricos}

La Odisea... cambia como el mar. Hay algo distinto cada vez que la abrimos. Borges, Los conjurados

\subsection{Nausica y la tierra de los feacios}

Nausica se consagra como personaje femenino protagonista tanto en la novela poemática de Pérez de Ayala, como en la obra teatral de Antonio Gala. Ambos autores recrean, en este punto, el Canto VI de la Odisea, en el que el héroe tras haber huido en una almadía de los poderosos encantos de Calipso en la Isla de Ogigia, es llevado por una violenta ola hasta un peñasco escarpado. De este modo, el héroe finalmente naufraga hasta Esqueria la fértil, en la playa de los feacios. Si la vida de los feacios dibujada por Homero en gran medida se asemeja a la imagen ideal y utópica de una colonia jónica alejada de toda inquietud y agitación (Rohde, 1983), el retrato de este espacio en Ayala y Gala se torna locus displicentis.

Si bien nos disponemos a analizar los episodios homéricos presentes en Prometeo de Pérez de Ayala y en ¿Por qué corres, Ulises? de Gala, en términos estructurales habría que puntualizar que en el caso de esta última, el escenario de Nausica, evocador de la tierra feacia, emerge como relato marco a partir del cual mediante la mimesis teatral se irán evocando de forma retrospectiva distintos episodios del poema homérico.

En la sección IV de Prometeo intitulada Marco y Perpetua, el narrador heterodiegético en tercera persona recrea el episodio de la llegada de Odiseo a la isla de los Feacios, cuando Perpetua - la Nausikaa moderna - se encuentra con un náufrago en la playa. El motivo literario que se ha tematizado es el de la llegada de un huésped, acogido en el palacio de Alcínoo (ahora por la marquesa), tal como en La Eneida Dido acogió al ingrato Eneas. El tono paródico a propósito de la ropa de Marco es innegable: "Busque usted por la comarca un hombre de mi cuerpo" (Pérez de Ayala, 1998, p. 620), llega a decir este Odiseo moderno que espanta con su figura a las compañeras de Nausikaa. El héroe moderno de Prometeo finalmente se viste con la ropa de Pepón, tildado de animal. La historia entre Perpetua y Marco permite introducir la antinomia individuo / sociedad, así como la repercusión que sobre el ámbito vital despliega:

Aquel era yo en mi individualidad más concreta. Luego fue conociendo usted poco a poco, gradualmente, la persona social de mí mismo, aquella complicación de usos, costumbres, atavíos, convencionalismos y demás externidades que componen la persona social, y las más de las veces no sirve sino para ocultar la miseria de la individualidad concreta.

(Pérez de Ayala, 1997, p. 625)

Según costumbre social española, es poco probable que los contrayentes se conozcan primero en su individualidad concreta. En este punto, Marco introduce toda una digresión o reflexión moral extrapolable a la sociedad española: "¿Qué es eso del amor? Cuando veo las parejas de novios, o mis amigas me cuentan sus amoríos, me hacen el efecto de personas fingidoras, afectadas, aficionadas a teatralerías y extremosidades; y por dentro, vaciedad o mentira" (Pérez de Ayala, 1997, p. 627).

Se aprecia así la falsía de muchas relaciones amorosas, sustentadas en un suntuoso aparataje teatral, colmadas de mentira y enraizadas sobre la base del matrimonio, en consonancia con el sentido moral de ¿Por qué corres, Ulises? El moderno Odiseo presentado por Pérez de Ayala recorrerá su particular periplo, desde su Italia natal hasta una España en decadencia. Accederá, 
así, a una Cátedra de griego en Pilares ${ }^{7}$ y se casará con una moderna Nausikaa, con la finalmente tendrá un hijo, ese falso Prometeo sobre el que proyectó sus ideales y al que verá fracasar, como si el poder del Superhombre de Nietzsche se hubiera desvanecido.

En el Canto VIII de la Odisea, luego de que el aedo divino Demódoco cante con altísima gloria la disputa de Odiseo y Aquiles Pelida —-provocando llanto en el héroe-, así como los amores de Ares y Afrodita, Odiseo se ve impelido a pedir al aedo que relate la acción del caballo de madera que Epeo logró realizar con ayuda de Atenea, así como el $\operatorname{ardid}^{8}$ con que el divino Odiseo y los teucros lograron penetrar en la fortaleza de Troya. Tras este episodio del relato de las hazañas o gestas gloriosas de los héroes, en el Canto IX de la epopeya homérica, Odiseo se convertirá en aedo y relatará en analepsis en el palacio de Alcínoo - ante un vasto auditorio-, los aventuras acaecidas en el país de los Cícones (Ismaro) o en la tierra de los Lotófagos ${ }^{9}$.

Así pues, en ¿Por qué corres, Ulises? se evoca este episodio del poema homérico en el que el héroe se encuentra instalado en el palacio de Alcínoo, junto a Nausica. Sin embargo, en la narración de Gala el relato comienza in medias res, puesto que no se cuenta la llegada de Ulises a la playa feacia, aunque se aluda al naufragio. El motivo del naufragio aflora no solo en la Odisea, sino también en la Eneida con la tormenta y, de manera desmitificada, en Prometeo de Pérez de Ayala. La omisión de este pasaje homérico de la llegada a la tierra de los Feacios en el inicio del Canto VI, otorga a la obra de Gala gran agilidad dramática, pues las grandes acciones del poema homérico se recrean mediante diálogo (mimesis), apenas con una pincelada del personaje, con un tratamiento liviano, pero donde subyace una crítica social encarnada en los personajes Ulises 75 y Nausica 75.

Ulises y Nausica llevan tres días y tres noches compartiendo el mismo lecho. Eurimedusa, quien amamantó a Nausica, le pregunta quién es el hombre que está junto a Nausica en el lecho. Este nuevo Ulises deberá el episodio de reconocimiento en la playa cuando su historia, mediante una analepsis, en el Palacio de Alcínoo ante los Feacios (López Férez, 2009, p. 49). En la narración homérica, Odiseo actúa como narrador interno (homodiegético, porque cuenta su propia historia). El reconocimiento del héroe en las obras de Homero y Gala se deja sentir de manera sustancialmente distinta.

\author{
NAUSICA: (Separándose de ULISES.) ¿Quién eres? \\ ULISES: Un hombre a quien los dioses no dejan descansar \\ NAUSICA: (Sentándose en la cama.) Si lo dices por mí... \\ ULISES: (Atrayéndola de nuevo.) No. Lo digo por los dioses. \\ NAUSICA: (Separándose sólo lo imprescindible.) Sólo sé de ti que la pelota con la \\ que yo jugaba te despertó hace tres días en la playa. \\ (Gala, 1975, p. 74)
}

Nausica tiene diecinueve años y todavía los hombres no han conseguido engañarla. Se aprecia, por tanto, una inversión de los tradicionales valores asociados a las edades del hombre. Aristóteles en su Retórica ofrece unas reveladoras palabras sobre el comportamiento del hombre

7 La Universidad literaria de Pilares en realidad es Oviedo (Calvo, 1991).

8 Este episodio es relatado de manera gloriosa en la Eneida de Virgilio. Reveladoras advienen las palabras de Laocoonte, sacerdote de Apolo Timbreo en Troya, quien advierte a los troyanos del engaño urdido por los griegos, en el célebre verso en hexámetros: "Timeo Danaos et dona ferentes" ("Temo a los griegos incluso cuando traen regalos") (Eneida, II, 49). Ese regalo es, de manera preclara, el caballo de madera realizado con estopa, en el que se introdujeron los griegos para asaltar las murallas de la ciudadela troyana.

9 El relato del periplo de Odiseo ya gozó de cierta autonomía narrativa durante la Antigüedad, de modo que se recitaba ante un auditorio como historia independiente. De hecho, la expresión Apólogos Alkinóou se utilizaba para designar una exposición larga y verbosa, de cierta unidad temática y estatus como el poema odiseico (Gómez Espelosín, 2000). 
en sus distintas edades:

Los jóvenes son por carácter concupiscentes, y decididos a hacer cuanto puedan apetecer. $Y$ en cuanto a los apetitos corporales son, sobre todo, seguidores de los placeres del amor e incontinentes en ellos. También son fácilmente variables y en seguida se cansan de sus placeres".

(Aristóteles, 12, 167)

Para Aristóteles los jóvenes están llenos de esperanza porque aún no han sufrido desengaño: aman y odian en exceso. Tal es el temperamento de Nausica, que se diferencia de la configuración del personaje de Odiseo en virtud de la acendrada madurez de este último. Antonio Gala ha elegido un héroe en edad avanzada para resaltar aún más sus rasgos de decrepitud y sentido ridículo, de manera que contrasta con el Ulises lleno de viveza del original homérico. A este respecto apunta Aristóteles (Retórica, 12, 168) que los hombre de edad avanzada ya han cometido errores y han sido engañados, por lo que en su carácter se incluye el ser malicioso y desconfiado: "Aman como quien luego ha de amar".

La edad del Ulises de Gala otorga una mayor comicidad a su fisonomía, en virtud de la modificación del episodio de llegada al país de los Feacios. Allí Nausica jugaba desnuda con la pelota, mientras que Odiseo se tapó su virilidad con una rama de olivo al verla. En la obra de Gala no encontramos el motivo de la acogida al huésped, hospitalidad tan inherente al sentido de los héroes homéricos. La Nausica 75 de Antonio Gala se muestra perfilada como un carácter individualista y temperamentalmente egocéntrica:

NAUSICA: [...] Ulises lleva tres días pensando en Ulises mientras besa a Nausica... para evitar eso, la especie ha inventado el matrimonio (Gala, 1975, p. 78).

Para Nausica la moral es una invención social: ella es un personaje moderno que siente el matrimonio como un convencionalismo. Es egoísta e individualista.

Como sostiene Nausica: "Es que, al verte en la playa, comprendí que eras un regalo del mar... y yo debía aceptarlo".

(Gala, 1975, p. 75)

En un momento singular de la obra de Gala, cuando Ulises se queda durmiendo, el diálogo entre Nausica y la nodriza Eurimedusa manifiesta el descrédito que ambas muestran ante los comentarios de Ulises. Nausica confiesa a su nodriza que Ulises le está contagiando su modo de hablar: invoca al Erebo, hijo del Caos y hermano de la Noche. En la misma línea, esta joven desmitificada se burla de Palas Atenea y de Poseidón. Si bien no lo desarrollaremos en este trabajo porque apenas se menciona, hay que destacar el comentario lateral que Nausica introduce sobre la antipatía que Poseidón profesa a Ulises, habida cuenta del episodio en que el héroe privó de la vista al cíclope Polifemo (Canto IX de la Odisea). En este pasaje el triunfo del héroe se produjo en aras de su astucia o inteligencia (metis).

La Nausica 75 de Gala está cansada de que Ulises se apreste continuamente a relatarle la Ilíada y la Odisea; y sin embargo, pospone su marcha:

NAUSICA: Es que lo quiero aún. Es un pesado, pero lo quiero, Me ha contado ya tres veces la llíada, cada vez de una forma diferente: lo que no cambia es que él se pone siempre de protagonista... pero lo quiero... La Odisea me la sé de memoria: si él se equivoca, y le sucede con frecuencia, lo corrijo... Pero lo quiero. Ningún hombre, hasta ahora, me inspiró lo que Ulises: ternura... No hay nadie que suscite más ternura que un héroe cansado. 
(Gala, 1975, p. 80)

Sin embargo, no es amor el sentimiento que brota del corazón de Nausica. Si bien la de níveos brazos se compadece de los héroes que regresaron de la guerra, del tono discursivo de Eurimedusa se desprende descrédito hacia los guerreros. Así, mientras Ulises 75 duerme, Nausica, Eurimedusa y Euríalo - el pretendiente de Nausica-, urden matar al héroe caído. Sin embargo, ni siquiera son capaces de matarlo y el héroe despierta. Frente al Ulises viejo y cansado, se muestra mediante prolepsis la figura del joven Euríalo, que deberá ocupar el puesto del viejo, tal como al final de la obra de Gala en que el hijo Telémaco sustituirá al padre y querrá alzarse como rey de Ítaca:

ULISES: (Muy desde arriba.) Es lógico. Si sólo hubiera un hombre. Lo amarías a él. Pero hay muchos y amas un poco a todos. Elegir uno solo entre tantos es difícil. A tu edad (Se está vengando.) es difícil. No te preocupes: el tiempo te ayudará a elegir. (Le pasa la mano por el pelo.) Por fin tendrás tu amor —el tuyo- al lado. Lo que no tendrás entonces será tiempo... Eso lo sé muy bien.

(Gala, 1975, p. 82)

La juventud de Nausica le impide elegir: Quiere tanto a Euríalo como a Ulises; no obstante, el héroe caído ya en la vejez le hace entender que cuando se tiene el amor al lado del hombre, ha llegado a la senectud y ya no tiene tiempo para gozarlo. Nausica, airada, osa despreciar a los dos amantes: se casará con un toro, como Pasífae de la que tanto le habla Ulises. Alcínoo, el padre de Nausica, no sabe que Ulises 75 ha llegado. Nausica está prometida con Euríalo, pero insta a Ulises a fingir ante su padre que encontró al héroe en la playa para que lo dé en matrimonio:

ULISES: Pero si yo me olvido de mi hogar, de mi esposa y mi hijo, tiene que ser por un amor eterno.

NAUSICA: Eres un burgués cursi, Ulises. Tú fuiste a Troya, has estado acostándote con quien te lo ha pedido por esos mares de Dios y ahora quieres hacerme responsable de tu hogar y tu hijo.

(Gala, 1975, p. 79)

Para Ulises, cuando el amor se acaba, queda el matrimonio, pues a su juicio se puede vivir muy bien sin el amor. Con el tiempo el hombre está menos seguro del amor, pero más seguro de la confianza en el otro. La moral falsa del Ulises 75 le incita a no buscar un sustituto cuando el amor se acaba, porque aunque el hombre viva sin el amor siempre encontrará cierta complacencia en el ámbito social con aquella persona a la que ha amado.

\subsection{La Guerra de Troya y el rapto de Helena}

La materia homérica tiene como trasfondo la guerra de Troya. Así pues, cuando el Ulises de Antonio Gala se encuentra junto a Calipso, la augusta, hija de Atlas y Pleione, este héroe desmitificado tratará de reivindicar su identidad, su condición de hombre glorioso. Para ello, inserta en su discurso comentarios a propósito de su idea sobre la invención del ardid del caballo de madera, sobre la guerra de Troya y las motivaciones que hicieron arraigar el conflicto. Sin embargo, cualquier intento de Ulises por reivindicar su nombre adviene absurdo en el contexto de 1975: “¿Qué importan nuestros nombres? Sólo nuestras obras merecen ser cantadas... Yo fui el inventor del caballo de madera" (Gala, 1975, p. 75).

La pátina irónica que atraviesa todo el pasaje recreado por Antonio Gala se acrecienta en la medida en que Nausica desconoce la historia del caballo de Troya, por lo que la escena deviene ridícula. El Ulises 75 se reivindica como rey de Ítaca: "Yo soy Ulises" (Gala, 1975, p. 75) y, de igual 
modo, este sucedáneo de héroe homérico pregunta a Nausica si ha oído hablar de su astucia (metis) y elocuencia. En este fragmento de la obra teatral, Antonio Gala está dibujando el ethos del personaje, en pugna perpetua con la tradición homérica, donde la metis del héroe es la inteligencia práctica para resolver cualquier problema. Sin embargo, Nausica no atisba en el personaje rasgo alguno de astucia. He aquí el tono de descrédito que adopta las palabras de Ulises. El héroe, ciertamente envejecido, tras diez años luchando en la Guerra de Troya y otros diez años errabundo por los mares de Grecia, insiste en ese paraíso perdido que fue su juventud:

\section{ULISES: (Con presunción y tristeza.) Pero hace veinte años yo era como un dios} joven...

NAUSICA: Y ahora eres como un dios maduro... las perdices están mejor un poco pasaditas. La fruta verde deja áspera la boca. Tú, no. Me gustas como eres.

(Gala, 1975, p. 76)

El Ulises 75 quiere reivindicar "la santidad del matrimonio. La estabilidad de los hogares. La dignidad de los maridos" (Gala, 1975, p. 76-77). Frente a la seguridad que representa Penélope, la Nausica de Gala simboliza el riesgo y el albedrío. Este héroe caído alude al motivo personal por el que se ocasionó la Guerra de Troya: el rapto de Helena, esposa de Menelao de Esparta, que llevó a cabo el Príncipe Paris. No obstante, para la mentalidad de Nausica, una mujer no se deja raptar si no quiere: "Solo por una rubia se hace una guerra" (Gala, 1975, p. 77) ${ }^{10}$.

\subsection{La ninfa Calipso y la isla de Ogigia}

Si bien en la obra de Antonio Gala se rememora como episodio marco el Canto VI de la Odisea, en que Ulises se halla en compañía de Nausica, esta pieza teatral alude de manera trasversal al Canto $\mathrm{V}$ del relato homérico, en que el que Odiseo se convierte en narrador interno de su propia historia para presentar la cueva de Calipso, la de crespos cabellos, en la Isla de Ogigia. Bajo la forma estructural de la mimesis inherente al teatro, el Ulises de Gala reproduce en estilo directo las palabras de la ninfa de crespos cabellos (Rogers, 1984; Paulino Ayuso, 1994; García Romero, 1999). En este punto, la fidelidad respecto del relato homérico es evidente, por cuanto el Ulises 75 de Gala se centra en el momento en que Calipso, la diosa entre diosas, se queja de que los dioses sean más celosos que nadie y dirigiéndose a ellos impreca: "No queréis que las diosas su lecho a las claras compartan / con el hombre mortal a quien quieren tener por esposo" Odisea, Canto VII, 591.

De esta manera, Ulises reproduce el discurso en estilo directo que Calipso, la de crespos cabellos, hubo de pronunciar ante el héroe homérico. Para ello, el Ulises 75 de Gala recuerda las palabras de la ninfa, cuando en Ogigia evocó el episodio en que los dioses manifestaron su envidia ante el amor entre Orión y la Aurora o entre Jasón y Deméter. Contrástense los discursos del Canto $\checkmark$ de la Odisea y la reproducción de este pasaje en los labios del Ulises de Gala:

\footnotetext{
Así cuando tomó a Orión ${ }^{11}$ la Aurora de dedos de rosa le tuvisteis envidia los dioses de vida apacible, hasta que Artemis casta, del áureo sitial, le dio muerte en Ortigia, asaetándolo con sus dulcísimas flechas. También cuando Deméter de crespos cabellos, cediendo
}

10 Esta frase podría evocar aquella pronunciada por Tersites en Troilo y Crésida de Shakespeare: "Y todo esto por una puta y un cornudo".

11 Cazador gigante, hijo de Poseidón que fue raptado por Eós y llevado a Delos. Al final Artemis le dio muerte con sus flechas al intentar violar a la hiperbórea Opis. 
a un impulso, entregóse a Jasón ${ }^{12}$ en amor y en el lecho, en su campo tres veces labrado, tardó Zeus bien poco en saberlo, y la muerte le dio con su rayo encendido.

(Odisea, Canto VII, 591)

ULISES: (Sin escucharla.) Un estremecimiento sacudió a Calypso y respondió: "Los dioses sois celosos. Nos negáis a las diosas el derecho a compartir la almohada con el mortal que nuestro corazón elige por esposo. Qué cólera sentís cuando amamos las diosas. ¿Es que en la vida vuestra puede caber algo más que alegría? Raptó la Aurora a Orión, y Artemisa, envidiosa y casta, lo alcanzó con sus flechas. Se enamoró Deméter de Jasón, entregándose a él sobre los surcos tres veces removidos y Zeus le acribilló con su rayo de Oro. A mí me traen a Ulises el viento y el oleaje. Lo recibo, lo abrazo, le prometo la juventud eterna... y el Olimpo, feroz, me lo arrebata".

(Gala, 1975, p. 79)

\subsection{La maga Circe en la isla de Eea}

Este aedo moderno en que se ha convertido el Ulises de Antonio Gala referirá sus escarceos amorosos con las enigmáticas Calipso y Circe. En cuanto a esta última, la materia literaria con la que Antonio Gala ha construido su pieza procede del Canto $X$ de la Odisea, en el que el héroe y sus compañeros llegan hasta la Isla de Eea. Cuando el héroe mandó a sus compañeros a explorar quién vivía ahí, encontraron a la maga Circe, hermana de Eetes terrible, engendrada por el Sol y cuya madre es Perse, hija del Océano. En torno a la casa de Circe, los compañeros encuentran lobos y leones que la maga había encantado con pérfidas drogas. La diosa de rizos bellísimos estaba cantando con voz dulce en la casa al tiempo que tejía, por lo que los compañeros, a excepción de Euríloco que se mostraba receloso, entraron en su morada. Circe los convidó con queso, harina y miel verde mezclada con vino de Pramnio y echó dentro de él perniciosas drogas.

La obra de Gala ¿Por qué corres, Ulises? elude todos estos detalles sobre los manjares con que la maga Circe convidó a los compañeros. Se centra únicamente en el detalle según el cual la diosa de rizos bellísimos convierte en cerdos a los compañeros. Tal episodio del que se nutre la obra teatral objeto de estudio se ofrece bajo un tratamiento distinto, en virtud de la particular perspectiva de descrédito que le otorga la Nausica 75:

ULISES: Sí, Circe, sin ir más lejos. La bellísima hechicera que convierte los hombres en cerdos. Se enamoró de mí... ¿Qué te parece?

NAUSICA: Que se enamorara de ti, normal: a cada cerdo le llega su san Martín. Pero que convirtiera a los hombres en cerdos me parece un trabajo innecesario. Siempre acaban por convertirse en cerdos ellos solos: basta dejarles tiempo.

ULISES. (Deseando apuntarse un tanto.) ¿Y Calypso, la Ninfa? También se enamoró de mí. De su isla vengo precisamente ahora...

NAUSICA: ¿Esa qué hacía? ¿En qué convertía a los hombres

ULISES: En amantes.

NAUSICA: Mucho más inteligente... Lo que me temo, pícaro, es que tú estés harto de ser famoso sólo por tu elocuencia. (Esto ha halagado a ULISES; lo que viene no.) A tu edad, es lógico que prefieras pasar a la Historia como un gran seductor. Ser lo que nunca se ha sido es una tentación...

(Gala, 1975, p. 78)

12 Hijo de Zeus y Electra, descendiente del gigante Atlas.

Panta Rei (2014), 71 - 95 


\subsection{La tierra de los Lotófagos}

En el escenario del Canto VI de la Odisea en que se recrea ¿Por qué corres, Ulises?, Antonio Gala alude de manera concreta al Canto IX de ese mismo relato homérico. En una estructura analéptica o retrospectiva, tanto en el relato homérico como en la pieza teatral de Gala, se rememora el episodio en que Odiseo, luego de que Zeus alzara un fuerte Bóreas y zozobrara la embarcación, llegó con sus compañeros a la tierra de los lotófagos, pueblo que come un florido alimento. Los hombres iban probando la pulpa melosa del loto no ansiaban ya la vuelta, pues preferían permanecer junto a los lotófagos, comienzo loto y olvidando el regreso a la patria. Este episodio homérico supone un ejercicio de alteridad, en el espacio de la isla alejado de la Ecúmene.

En este pasaje el peligro no es apreciable a primera vista, pues los Lotófagos acogen de modo favorable a los expedicionarios, si bien a costa de provocarles el olvido de sí mismos (Gómez Espelosín, 2000). El temor al olvido del retorno en la epopeya homérica se modifica y encumbra en la obra de Gala, donde al final de la pieza teatral el lector advierte que realmente al Odiseo 75 no lo movía a regresar causa alguna. El Odiseo de Homero tuvo que conducir llorando a sus compañeros hasta las naves. En la obra teatral de Gala, por su parte, no se subvierte en términos paródicos este episodio homérico. Al contrario, Ulises evoca este pasaje porque Nausica así se lo pide, si bien no logra terminarlo porque la joven no hace sino interrumpir:

NAUSICA: [...] Cuéntame lo que te pasó en aquella isla donde los hombres se alimentaban con la flor del loto. No lo recuerdo bien...

ULISES. (Halagado en lo íntimo.) El loto hace olvidar los hogares, la patria, el ideal y los hijos...

NAUSICA: (Interrumpe, indebidamente, por ganas de participar. Pero a ULISES le fastidia.) Cuando yo era una niña me sentaba con la falda llena de paniquesillo al pie de las acadias...

(Gala, 1975, p. 84)

\subsection{Ideas sobre la muerte y la inmortalidad. La Nekuia o descenso al Hades}

En ¿Por qué corres, Ulises? aflora un comentario lateral del episodio homérico sobre la nekuia o descenso a los infiernos ${ }^{13}$. Ese comentario es puesto en boca de Penélope cuando, de repente, emerge un diálogo entre Penélope y su esposo del que ni ellos mismo podrían dilucidar si es realidad o sueño. Ante la duda del Ulises 75 sobre si su esposa está muerta, ella le pregunta: “¿No estuviste en el sombrío Hades, el país de la muerte? ¿No te rodeó allí la vaga procesión de las princesas muertas, que anhelaban beber la sangre del carnero sacrificando? ¿Me viste a mí entre ellas? Mírame bien, Ulises" (Gala, 1975, p. 85).

El episodio de la nekuia o visita al mundo de los muertos confiere significación plena al periplo odiseico, en tanto prueba definitiva en la que el héroe se enfrenta cara a cara con la muerte (Gómez Espelosín, 2000). Sin embargo, en la obra de Gala la perspectiva de Penélope otorga cierto descrédito a la nekuia del personaje. Si el héroe se encuentra en el Hades con distintos personajes, como Aquiles quien le revela la vanidad de los ideales heroicos, en ¿Por qué corres, Ulises? esos ideales se han quebrado.

La idea homérica sobre la vida sombría de las almas de los muertos emerge como resignación (Rohde, 1983). Según refiere Menelao a Telémaco en el Canto IV de la Odisea, Proteo le contó las condiciones en las que regresaría a su patria, con el paso obligado por los Campos Elíseos,

13 La nekuia es también un rito en relación con los viajes de Anábasis y Catábasis. En concreto, se manifiesta como una catábasis o descenso al inframundo y su consecuente ascenso (anábasis), que ha nutrido el imaginario sobre las creencias funerarias en buena parte de las civilizaciones del mundo. El Poema de Gilgamesh ofrece un testimonio temprano sobre la muerte de su amigo Enkidu, acorde con los ritos funerarios. 
en los confines de la tierra donde mora Radamante. Según creencia homérica, los dioses pueden conceder la inmortalidad a los mortales. Sin embargo, Odiseo rechaza vivir eternamente junto a Calipso, quien le ofrecería la inmortalidad y lo eximiría de la vejez para siempre (Rohde, 1983).

Esta asimilación a la naturaleza divina es inexistente en el imaginario cultural de las obras de Ayala ${ }^{14}$ y Gala, en razón de una pérdida del sentido de la trascendencia. La invención de los Campos Elíseos se instituye en Homero como refugio póstumo de la esperanza humana. Sin embargo, para la inventiva poética cifrada en el imaginario cultural del siglo XX, ni Pérez de Ayala ni Gala conciben unos asideros teológicos ni siquiera espirituales. El Ulises de Ayala y Gala es un personaje sin fe, que no sueña paraísos inexistentes, sino que se refugia en una moral de época, acorde con la sociedad decadente en Prometeo y el convencionalismo y la falsedad en ¿Por qué corres, Ulises?

\subsection{El regreso imposible. Ítaca y Penélope, la tejedora eterna}

Cuando emprendas tu viaje a Ítaca, pide que el camino sea largo, lleno de aventuras, lleno de experiencias. Kavafis, Ítaca

Si las figuras homéricas de Circe y Calipso —en contrapunto con Penélope- personifican la pasión y la afectividad no doméstica, la esposa de Ulises se establece como epítome de la afectividad y pasión hogareña (Stanford, 2013). Penélope como personaje e Ítaca como lugar de regreso advienen en tanto meta del viajero. También al final del Ulises de Joyce, el héroe regresa junto a Penélope. Sin embargo, en la simbología alegórica de las obras de Pérez de Ayala y Gala, tal regreso se manifiesta como frustración o imposibilidad de trascender.

En la obra teatral de Gala, Ítaca simboliza el amor sustentado en la convivencia, de la que Penélope es figura en que el héroe caído se afirma en la costumbre (Martínez Moreno, 1994). Por eso, Ítaca y Penélope en ¿Por qué corres, Ulises? constituyen una evocación desde Esqueria, un anhelo onírico enmarcado en la ficción del héroe sin entidad real. En labios de Penélope se refleja esta idea, cuando se dirige a Ulises: "Yo no soy más que un reflejo de tu ingenio" (Gala, 1975, p. 60 ). Ello provoca el desencanto final del Ulises de Gala, con la amargura de la imposibilidad de vivir según las convenciones en la España de la posguerra.

Esa perspectiva femenina que en la epopeya homérica resulta inexistente, se aprecia de manera lúcida en ¿Por qué corres Ulises?, donde Nausica descree de que Penélope después de veinte años espere todavía al héroe. La mujer de Ulises no puede ser más que una tejedora, no ya de sueños, sino de una realidad profunda: el tiempo pasa y el gobierno de Ítaca ya no le corresponde al decrépito Ulises sino al joven Telémaco (García Romero, 1999, p. 513). A Ulises le molesta la insolencia de Nausica en cada una de sus réplicas, porque él quiere una mujer ideal, una Penélope inexistente, cuyo esbozo no se halla más que en la mente de Ulises: que sea menos viva de genio.

En ¿Por qué corres Ulises?, Penélope recibirá al héroe como Ulises soñó. Las aserciones de Ulises no se corresponden con el tono de la obra: espera que Penélope lo aguarde en Ítaca y que su hijo Telémaco no tenga el mismo temperamento que Nausica. De esta manera, se invierte el sentido de un procedimiento singular de la epopeya homérica: la prolepsis o anticipación, puesto que se anticipa un hecho que sucederá después: Penélope no es tal como el héroe ha soñado y su Hijo pretende alzarse con el trono de Ítaca.

14 La alusión a la catábasis o descenso al Hades adquiere una formulación más implícita en Prometeo, donde en la sección II (Odysseus) se menciona el descendimiento del héroe hasta una ciudad muerta del centro de España, donde pudo consultar al sabio Tiresias con cara de búho (don Miguel de Unamuno). A partir de ese momento, tal como le revela Tiresias, el héroe ya no será más que el recuerdo de un hombre. En el poema homérico, sin embargo, no hay propiamente un descenso al Hades. 
ULISES. - Lo que una vez fue nuestro y perdimos nos atrae siempre; pero solo porque lo perdimos. Si lo volvemos a gozar, vuelve a cansarnos... cómo gana una mujer mientras se la sueña. Ay, Penélope, vete, quiero soñar contigo... Circe y Calypso no se apearon del pedestal: siempre fueron soñadas.

(Gala, 1975, p. 84)

En la segunda parte de la obra de Gala, se evoca el episodio odiseico de los pretendientes, en concreto la prueba por la que Penélope promete que se casará con aquel que tienda el arco de Ulises. Sin embargo, estos pretendientes —entre ellos Agelao- se echan a reír. Mediante una carta Eurimena hace saber a Penélope que Ulises ha muerto, pero a Penélope no le conmueve. Penélope evoca el pasaje de la Odisea en el que un jabalí hirió a Odiseo ${ }^{15}$ cuando éste se encontraba con su abuelo Autólico. Si bien a Penélope le endulza este recuerdo, ya no espera a su esposo:

Las infidelidades lo son porque hay alguien a quien serle fiel, aunque no lo seamos. A Ulises pude ponerle los cuernos y engañarle. A mí no me engañaba... A partir de hoy, casada, ya no podré engañar a Ulises ni serle fiel. Ulises ya no cuenta. No debo ya esperarlo...

(Gala, 1975, p. 66)

Penélope ha advertido a un pretendiente anciano (Anfínomo) de que en el arco de Ulises hay un truco para que nadie pueda tenderlo. Penélope no quiere casarse por amor la segunda vez. Ulises emerge como una sombra para evocar a su "dulce, callada y obediente" esposa, que cree en el nuevo reinado de su hijo Telémaco. De este modo, Ulises se presenta como símbolo del hombre "eterno insatisfecho, viajero, curioso, razonador, dominador de la naturaleza, contrincante mañoso del destino, desobediente a los dioses malignos" (ibídem, p. 78). La Penélope de Gala abomina de su condición de esposa y madre modelo. Quiere embriagarse en la bebida para paliar su fracaso ${ }^{16}$. La decepción final aflora en palabras de Ulises "Triste es llegar a la patria, Penélope, después de tantas privaciones y encontrar que solo un perro nos reconoce" (Gala, 1975, p. 91).

\section{Procedimientos y recursos de la narración homérica}

\subsection{La descripción o écfrasis de escenas}

Los espejos deberían reflexionar antes de devolver una imagen.

Jean Cocteau

En Prometeo, cada una de las cinco secciones en que el autor ovetense estructura su obra (Rapsodia a manera de prólogo, Odysseus, Nausikaa, Marco y Perpetua y Prometeo) se ve precedida

15 Se trata del episodio que Homero relata en el Canto XIX de la Odisea: "El primero que se decidió a atacar fue Odiseo: /levantó con su mano robusta la lanza larguísima / proponiéndose herirlo, mas el jabalí, anticipándose, / le clavó en la rodilla el colmillo y, rasgándola al sesgo, / se llevó mucha carne, mas no interesó nada el hueso". Este pasaje homérico ha nutrido buena parte de la tradición literaria occidental, en el memorable capítulo intitulado La cicatriz de Ulises, donde Auerbach en su obra Mímesis. La representación de la realidad en la literatura occidental (1942), se recrea en el reconocimiento de Odiseo por parte de la nodriza Euriclea.

16 Véase El nacimiento de la tragedia de Nietzsche, en concreto, el capítulo sobre La visión dionisíaca del mundo, en relación con la filosofía griega y su culto a dos divinidades: Apolo y Dionisio, este último en relación con el sueño y la embriaguez. A este respecto, podría interpretarse la actitud de Penélope como un acercamiento al espíritu dionisíaco, frente a la condición apolínea de esposa modelo que quisiera atribuirle Ulises. 
por un poema que sintetiza y preludia el contenido subsiguiente. Esta forma narrativa breve permite una estructura dual de los acontecimientos, así como la combinación de géneros literarios, primero mediante el verso y luego a través de la prosa. Así pues, la forma versal es el mecanismo en virtud del que se anticipan los acontecimientos desarrollados luego bajo el molde de la prosa.

Sin embargo, más allá de esta significación formal, la presentación de los acontecimientos a la manera de microescenas guarda un estrecho paralelismo con la narración homérica, en este caso, tanto con la llíada como con la Odisea. Dentro de la categoría de la ekphrasis o descriptio, un procedimiento singular es la mise en abyme (Dällenbach, 1977). Procedente de la literatura medieval, en concreto del ámbito de la heráldica, la puesta en abismo nos permite asomarnos a una realidad al modo de la microescena que, presentada bajo el molde de la forma lírica, luego se relatará a mayor escala mediante la narración en tercera persona.

\subsection{Mimesis y diégesis}

En la novela poemática de Pérez de Ayala emerge un narrador heterodiegético, en tercera persona, que relatará el periplo que conducirá al protagonista hasta su particular Ítaca: desde su Italia natal hasta una España decadente. En esta obra se imbrica, pues, la perfecta estructuración de la diegesis con la alternancia de la mimesis o partes dialogadas, en cuya virtud el narrador cede la palabra al alma de sus criaturas ${ }^{17}$. En esas partes dialogadas de carácter mimético afloran lúcidas reflexiones sobre aspectos candentes en la Generación del 98: el hombre de pensamiento frente al de acción o la búsqueda de la armonización de los contrarios en la sociedad española de la época. En esta línea, habría que establecer una diferenciación en el modo de presentación de los acontecimientos tanto en la novela de Pérez de Ayala como en la obra teatral de Gala. Mientras que esta última ha de adaptarse a las convenciones inherentes al género dramático, cual es el carácter mimético y la estructura enteramente dialogada, la novela poemática de Pérez de Ayala integra narración y diálogo.

Las diferencias entre una novela breve y una obra de teatro resultan sustanciales, en la medida que condicionan la presentación y el tratamiento de algunos pasajes respecto del fermento original fijado en la narración homérica. Frente al carácter de inmediatez de la mimesis o forma dialogada, se manifiesta el ritmo narrativo lento y condensado de la diegesis, donde el narrador en tercera persona puede distender su relato todo el tiempo que considere.

\subsection{Oralidad y escritura: Del cantar al contar}

Canto y cuento es la poesía.

Se canta una viva historia contando su melodía. Antonio Machado, De mi cartera

La poesía, desde la noche de los tiempos, se ha asociado a la música. Las Sirenas en el Canto XII de la Odisea entonaron a Ulises una melodía indescriptible, pues la música es anterior a

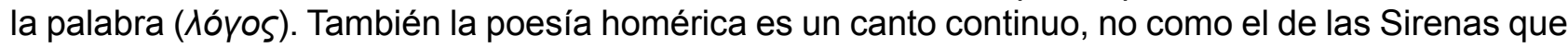
provoca el olvido del navegante que ha de retornar a su patria, pero sí como oralidad que resuena en el imaginario de la cultura occidental.

Prometeo de Pérez de Ayala se inaugura con un proemio ${ }^{18}$ a la manera de exordio o captatio benevolentiae, mediante una rapsodia con la que se evoca un elemento fundacional de la literatura: la figura del rapsoda y la rapsodia, en tanto forma poética de carácter oral que lo singulariza. Al igual que en la narración homérica, encontramos a los aedos Femio y Demódoco - a la manera de mise

17 Es interesante la aportación de Genette (1966). El teórico francés se basa en las ideas que Platón estableció en República (Libro III) sobre los distintos modos de narración.

18 La funcionalidad del proemio (proemium) en términos de Curtius (1995), es característico del relato.

Panta Rei (2014), 71 - 95 
en abyme-, porque a pequeña escala emergen como reflejo del poeta Homero. Sin embargo, en el comienzo de la narración de Pérez de Ayala ("Rapsodia a manera de prólogo") se atisba la figura de un narrador moderno. Al inicio de la novela atisbamos el paso de la oralidad propia del aedo a la palabra escrita del novelador, cántico doloroso a la pérdida de la oralidad que entonaría Walter Benjamin a las alturas de 1936 en su lúcido ensayo El narrador:

Así, lo que en las edades épicas fue canto heroico al son de la cítara, es ahora voz muda y gráfica, esto es, palabra escrita, sin otro acompañamiento que la estridencia lánguida de la pluma metálica sobre el papel deleznable. El aedo ha degenerado en novelador.

(Pérez de Ayala, 1998, p. 594).

El narrador de Prometeo añora la heroicidad de la gesta homérica entonada al son de la cítara: "Canta o cuenta, joh diosa chismorrera y correveidile!" (Pérez de Ayala, 1998, p. 594). Apologista de la oralidad, el narrador de esta novela poemática siente la figura del novelador o novelista como una degeneración del aedo (en sentido etimológico, cantor), por cuanto se han sustituido los encantos de la música por la frialdad del papel. A diferencia de la obra teatral de Gala, en la novela poemática Ayala el narrador aludirá al aedo Homero, epítome de la oralidad, por ser "el de los ojos sin luz", el ciego de Quíos, entroncando así con toda una tradición profética donde ceguera y sabiduría actúan como conceptos solidarios. Bastaría citar a Milton, secretario de cartas latinas de Cromwell; a Borges, el ciego argentino explorando con el "báculo indeciso"; o al adivino Tiresias a cuya ceguera se le atribuía buena parte de su valor profético y sapiencial.

Si con la pérdida de la oralidad se abandona la sabiduría del primer aedo Homero, el paso del cantar al contar nos conduce directamente a su etimología (computare), en una relación entre el contar numérico y los hechos relatados. Prometeo, sin embargo, se distancia de esta concepción del canto heroico de la épica, en la que la figura del novelador o novelista se considera un aedo venido a menos. Por su parte, en ¿Por qué corres, Ulises? está presente la idea del contar, esta vez no de manera novelesca, sino mediante la mimesis inherente al género teatral:

NAUSICA: No te pongas triste. Toma (Le ofrece algo de alcohol.) (ULISES acepta.) Y cuéntame tu vida, que me parece que es lo que más te descansa... (Disponiéndose a escuchar más por educación que por verdadero interés.) ¿Por qué dejaste Ítaca?

ULISES: (Cuando es escuchado le gusta hacerse el misterioso.) Por defender unos principios.

NAUSICA: ¿Cuáles?

ULISES: La santidad del matrimonio. La estabilidad de los hogares. La dignidad de los maridos.

NAUSICA: (De corazón.) ¡Qué antiguo, Ulises! (Viendo la reacción, vuelve a su tono superficial.) ¿Y qué hiciste para defender esos principios?

ULISES: La guerra de Troya.

(Gala, 1975, pp. 76-77)

Sin embargo, en la obra de Gala no arraiga ese sentido de la admiración (admiratio) ante el relato del héroe tan presente en la epopeya homérica, donde el héroe se erigía como narrador interno en primera persona de su propia historia. El Ulises 75 menciona el marco histórico de la Guerra de Troya y el motivo personal por el que se ocasionó: el rapto de Helena. En este punto, la narración de Gala se encuentra en ese limbo entre el cantar y el contar. Es un canto en la medida en que la obra de teatro se escribe para ser representada; sin embargo, de su oralidad no queda más que el beneplácito del héroe por cantar su historia, como si se tratara de un aedo. 


\section{El estadio postmoderno de la parodia: $\operatorname{Re}(b)$ velar a Homero}

Aristóteles en su Poética apenas refiere nada a propósito de la parodia ${ }^{19}$. Al establecer una teoría de acuerdo con la dignidad moral o social de los géneros literarios, sitúa la parodia en relación con la comedia, acorde con una acción baja en el modo expresivo. Existe, por lo tanto, una ausencia sobre el sentido de parodiar (Gómez, 1990). Por esta razón, Genette deduce que la parodia implica una cierta burla respecto de los géneros nobles o serios establecidos ya desde la tradición griega. En concreto, la parodia se singulariza por su burla respecto de la epopeya, modificando el espíritu y cariz de un tema heroico, que deviene vulgar frente a la nobleza o estatura trágica presente en el origen.

Ya desde la tradición griega la parodia emerge como contrafaz de los géneros nobles. A este respecto, Bajtin (1989) sostuvo que en la literatura antigua tardía era frecuente parodiar las obras de Aulo Elio, Plutarco, Ateneo o Macrobio. También en el drama satírico, concretamente en el cuarto drama que sucedía a la trilogía clásica, se abordaban los mismos temas mitológicos de la trilogía, pero con un tratamiento paródico. Otro ejemplo revelador sobre el sentido de la parodia casi desde los orígenes de la literatura en Occidente se refiere al drama de Esquilo El coleccionista de huesos, en que se recreaban héroes de la guerra de Troya de manera paródica. Los personajes homéricos también eran susceptibles de ser parodiados, por lo que tanto el Ulises cómico como el Hércules cómico gozaron de gran popularidad, e incluso a Homero se le atribuyeron obras como El combate de los ratones y las ranas o el poema cómico sobre Margites el Tonto (Genette, 1989).

\subsection{Estilemas o marcas de estilo}

A propósito de la estilización expresiva del lenguaje, escribe Bajtin que el autor habla mediante la palabra ajena (Pozuelo, 2007, p. 270). Según Bajtin, los textos de los que se desprenden rasgos paródicos se construyen de acuerdo con una determinada configuración formal, en cuyo artificio el texto A (hipotexto), objeto de parodia y texto base (la Odisea homérica), hace ostensible y palpable rasgos expresivos o marcas de estilo (estilemas) del texto B (hipertexto) (Genette, 1989). Así pues, emerge una dialéctica conflictiva entre la autoridad del texto $A$ y la subversión que sobre el texto base está operando el texto $\mathrm{B}$. Esa palpabilidad en el texto parodiado aflora en las fórmulas de índole lingüístico-semántica y formal del texto sobre el que se construye la parodia.

Aunque son muchos los pasajes graves de la obra, Pérez de Ayala alterna con un estilo humorístico, limítrofe con la parodia, por lo que se manifiestan constantes estilizaciones lingüísticas o estilemas. Desde el inicio de la novela poemática, un lector avezado puede percibir la reproducción del inicio de la obra homérica. Frente al comienzo de la Odisea "Habla [canta], Musa, de aquel hombre astuto que erró largo tiempo", (Homero, Odisea, Canto I), Pérez de Ayala remeda el estilo

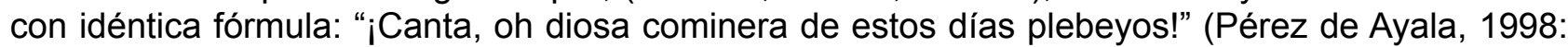
594). Sin embargo, habría que puntualizar que el acto de remedar estilos literarios no siempre se aplica en relación con un texto paródico. Sin embargo, suele existir una relación de intertextualidad (Genette, 1989), como si el texto nuevo actuara a la manera de palimpsesto o pergamino reutilizado sobre el cual el autor moderno escribe según algunos fundamentos del texto precedente. A este respecto, un ejemplo digno de mención se encuentra en El Paraíso Perdido (1667) de Milton, donde en el Pandemonio o palacio de Satán se canta la primera desobediencia del hombre:

Canta, celeste Musa, la primera desobediencia del hombre, y el fruto de aquel árbol prohibido, cuyo funesto manjar trajo la muerte al mundo y todos nuestros males,

19 Es interesante la etimología del término parodia: ôda es canto y para-, "al lado de" o "fuera de", por lo que parodêin alude al hecho de cantar deformando la melodía original que sirve como modelo (Genette, 1989). Igualmente, interesa la definición de comedia inserta en la Poética de Aristóteles (V): "La comedia es, como hemos dicho, mimesis de hombres inferiores, pero no en todo el vicio, sino lo risible, que es parte de lo feo".

Panta Rei (2014), 71 - 95 
con la pérdida del Edén, hasta que un hombre más grande reconquistó para nosotros la mansión bienaventurada.

(Milton, 1979, p. 12)

Si bien la invocación a la Musa constituye desde el relato homérico un rasgo fundacional de la épica ${ }^{20}$, según los periodos literarios se suele modificar su clave interpretativa: como advertencia contra la tentación en El Paraíso Perdido, como parodia desmitificadora en Prometeo y ¿Por qué corres, Ulises? e incluso de manera más reciente como intertextualidad y homenaje a la cultura literaria, en un breve texto de Luis Landero, en que el autor se apropia de los referentes artísticos que han nutrido su imaginario a través de la lectura:

Canta, oh diosa, no sólo la cólera de Aquiles sino cómo al principio creó Dios los cielos y la tierra y cómo luego, durante más de mil noches, alguien contó la historia abreviada del hombre, y así supimos que a mitad del andar de la vida uno despertó una mañana convertido en un enorme insecto, otro probó una magdalena y recuperó de golpe el paraíso de la infancia, otro dudó ante la calavera, otro se proclamó melibeo, otro lloró las prendas mal halladas, otro quedó ciego tras las nupcias, otro soñó despierto y otro nació y murió en un lugar de cuyo nombre no me acuerdo. Y canta, oh diosa, con tu canto general, a la ballena blanca, a la noche oscura, al arpa en el rincón, a los cráneos privilegiados, al olmo seco, a la dulce Rita de los Andes, a las ilusiones perdidas, y al verde viento y las sirenas y a mí mismo.

(Landero, 1996, p. 51) $)^{21}$

A diferencia de la Odisea y El paraíso perdido, el carácter ostensible y palpable del estilo continúa en Prometeo como marca expresiva de la parodia:

Canta o cuenta, ;oh diosa chismorrera y correveidile!, cómo el divino Odysseus, nacido en la ciudad en donde Areas fue derrocado por el Bautista, partió para la sagrada llios, cuya ciudadela tomó por la eficacia de su ingenio; y cómo luego visitó la tierra de los lotófagos, los cuales se alimentan de una flor que hace perder la memoria y proporciona el dulce don del olvido, y, huyendo de ellos, padeció males sin cuento y fue a caer en los brazos de la venerable y encantadora Kirke, de abundosos cabellos; y cómo gracias a Hermeias, dios del bastoncillo de oro, que mantiene en todo punto la gracia adolescente, se libertó de la maliciosa y ardiente Kirke, y descendió a las moradas de Aides $^{22}$, país lamentable florecido de asfódelos, por donde vagan las cabezas vacías

20 Es muy significativa, a este respecto, la formulación del proemio o invocación a la Musa en las Argonáuticas de Apolonio de Rodas, donde la invocatio que ha de traer la inspiración sirve de motivo estructurador del poema, al inicio de los libros I, III y IV.

21 Afloran en el relato de Luis Landero guiños intertextuales pertenecientes a distintas épocas literarias: la invocación a la Musa del Canto I de la llíada, el versículo I del Génesis, Las mil y una noches, el libro V (De brevitate vitae) de los Tratados morales de Séneca, el comienzo de la Divina Comedia de Dante, la evocación a La metamorfosis de Kafka, el primer volumen (Por el camino de Swann) de En busca del tiempo perdido de Marcel Proust, la tragedia Hamlet de Shakespeare, el acto I de La Celestina de Fernando de Rojas, el soneto $\mathrm{X}$ de Garcilaso de la Vega ("iOh, dulces prendas por mi mal halladas!”), Edipo, rey de Sófocles, La vida es sueño de Calderón de la Barca, el Canto General del poeta chileno Pablo Neruda, Moby Dick de Herman Melville, el poema Noche oscura de San Juan de la Cruz, la rima VII de Gustavo Adolfo Bécquer, Luces de Bohemia de Valle-Inclán, el poema A un olmo seco de Antonio Machado, el poema Idilio muerto de César Vallejo, Las ilusiones perdidas de Honoré de Balzac, el Romance sonámbulo de García Lorca, el Canto XII donde aparecen las Sirenas de la Odisea de Homero y, por último, el Canto a mí mismo inserto en la obra Hojas de hierba de Walt Whitman.

22 Hades o Inframundo. 
de los que dejaron de existir, allí interrogó a Tiresias, adivino de mucha reputación en la antigüedad mítica, y oyéndole y viéndose cercado de sombras incorpóreas, el ilustro y sutil Odysseus, a pesar de su espíritu inmutable, sintió en sus miembros el pálido terror; y cómo sus compañeros hicieron matanza y comieron de los rebaños de Helios, que todo lo ve, y movieron a los inmortales a venganza; y cómo el excelente Odysseus, de la propia suerte que los demás hombres menos excelentes y nada excelentes, anduvo entre Skyla y Kharybdis, que también se dice de Herodes a Pilatos; y cómo se holgó, a pesar suyo, en el ameno antro de la mimosa ninfa Kalypso; canta o cuenta, sobre todo, ioh diosa sabihonda!, cómo el moderno Odysseus encontró a Nausikáa, de los brazos blancos, porque es lo único que verdaderamente nos interesa en este punto.

(Pérez de Ayala, 1998, pp. 594-595)

Mediante esta enumeración que sintetiza las distintas aventuras del héroe, se produce el cómputo (computare) al que aludíamos con el capítuloXX de El Quijote. La recapitulación de elementos no solo manifiesta el recorrido del héroe, sino también la modificación de los acontecimientos y la focalización en el episodio de Nausica. En Prometeo también los nombres de los personajes se han modificado. Calipso es la rolliza Federica Gómez, viuda de un anciano, que recuerda a la Aldonza Lorenzo hermoseada como Dulcinea por nuestro simpático hidalgo. Asimismo, la ambrosía ya no es la bebida de los dioses, el elixir servido por Ganímedes, el copero de Zeus, sino vino y aguardiente.

Para los antiguos, la dádiva de vislumbrar el Paraíso radicaba en alcanzar el nombre verdadero como enigma de la revelación (Blumenberg, 2003). Sin embargo, Nausikaa presenta en la novela poemática de Pérez de Ayala el apellido poco eufónico de Perpetua Meana, de igual modo que Circe se ha transmutado en Lolita la de la Carne, así como Odiseo es Antonio Pérez Fillol o, en su defecto, Marco de Sentiñano. Aflora también la burla hacia Agamenón, rey de Micenas asesinado por su esposa Clitemnestra, tildado de "pollino" en esta novela poemática ${ }^{23}$.

En Prometeo de Pérez de Ayala, el autor nos conduce hacia un espectáculo paródico a partir de los rasgos del género parodiado (la épica), mediante la hipertrofia y el exceso de su forma. En ¿Por qué corres, Ulises?, sin embargo, la parodia adviene como rebajamiento de la fisonomía y el carácter elevado con que se perfilaban los héroes en la epopeya homérica. Frente a esa palpabilidad o carácter ostensible en la forma y expresión de Prometeo, ¿Por qué corres, Ulises? apenas reproduce los rasgos expresivos de la forma homérica.

He aquí una diferencia sustancial entre ambos textos, pues en la pieza teatral de Gala el cariz paródico adviene en la medida en que se evocan mediante la mimesis episodios homéricos desmontados, trocado el argumento y desarrollo de los hechos. En esta línea, ¿Por qué corres, Ulises? participa de un fenómeno que Bajtin (apud Pozuelo Yvancos, 2007) ya supo apreciar a propósito de obras de la antigüedad en que se parodiaba la heroización épica. Precisamente, el personaje de Nausica en la obra de Gala está parodiando a héroes pertenecientes al marco de la Guerra de Troya (Helena, Áyax, Agamenón o Clitemnestra) y, al mismo tiempo, se convierte en parodia de sí misma, joven desmitificada, libidinosa, lujuriosa, lúbrica y retozona, que dista mucho de la Nausica virginal, de níveos brazos tal como la presenta Homero. Véase este ejemplo de la obra de Antonio Gala, donde se condensa el ethos de muchos de los héroes sometidos a escarnio:

NAUSICA: Helena fue una puta pasada de moda. Menelao, un cornudo consentido. Clitemnestra una perra salida, a la que su marido no dejaba contenta. Agamenón, un

23 Ya Cervantes se sirvió con maestría de este fenómeno de rebajamiento onomaseológico en el capítulo XVIII de EI Quijote, cuando se dispone a mencionar los nombres de los distintos capitanes: "el señor de la trapovana" (en lugar de tropa vana); "Pentapolín", en sentido etimológico cinco veces burro; o el topónimo "carcasón", ciudad medieval amurallada que alberga la palabra carcajada. No hay Paraíso para los héroes caídos. Los nombres delatan su condición de baja estofa, según la tradición instaurada desde el Crátilo de Platón, en virtud de la cual el nombre es arquetipo de la cosa designada (designatum). 
impotente que se distraía jugando a los soldados...

ULISES: (Sin agraviarse.) Deja en paz a los muertos.

NAUSICA: ¿Dejaron ellos en paz a los vivos? Áyax, un esquizofrénico consumido de envidia. París, un barbilindo parpadeando, especializado en concursos de belleza... Y tu héroe Aquiles, el de los pies ligeros...

ULISES. (Como a una niña.) Calla, Nausica...

NAUSICA: (Imparable.) Aquiles, una loca a la que le importaban más que los que mulos de Patroclo... Y tu Olimpo ¿me oyes bien? todo tu Olimpo, un patio de vecinos atestado de zorras y maricas.

ULISES: (Sin inmutarse.) No blasfemes. iTe has vuelto loca! Los dioses...

NAUSICA: Pero el peor de todos, tú: explotador de viejas solitarias, consolador de solteronas, mentiroso, bujarrón de puertos, bravo de pacotilla, adorador de dioses inventados...

(Gala, 1975, p. 84)

Tras este parlamento descriptivo como el ethos del Ulises 75 , el héroe caído de Gala abofetea a Nausica. En definitiva, las situaciones procaces y el lenguaje abyecto que raya en lo soez configuran, tanto en la narración de Ayala como la obra teatral de Gala, una representación imaginaria que reformula el mito clásico y que solo mediante una contextualización puede comprenderse su sentido. Esa procacidad del lenguaje desvirtúa la nobleza de los héroes homéricos. Antes que encumbrarlos, da buena cuenta de la pérdida de sus atributos heroicos.

\subsubsection{El arte del epíteto como parodia estilística}

Otro indicio de estas marcas de estilo viene a constituirse mediante los epítetos. El adjetivo o mejor llamado epíteto debiera incluirse dentro de los llamados motivos colaterales o detalles, en terminología de Tomachevski (1982), por cuanto ofrecen una información adicional de diversa índole sobre el personaje retratado. Así pues, en Prometeo Nausica es la "de los brazos blancos" en consonancia con "la de níveos brazos" homérica; Poseidón, "el que rige los mares"; Kirke "de abundosos cabellos", en la Odisea adjetivada como "la diosa de rizos bellísimos"; Helios "que todo lo ve"; y Hermes o Mercurio , "dios del bastoncillo de oro", que en el relato homérico porta el caduceo o bastón de oro que le fue regalado.

Estos epítetos abundan en cualidades del personaje, sirven para identificar a los héroes o dioses y, como recurso mnemotécnico, permiten al aedo completar un hexámetro durante la recitación. El epíteto describe cualidades físicas y psicológicas del personaje, en tanto que describe rasgos de su ethos. En Homero son muy frecuentes los epítetos que se dilatan por espacio de varios versos y, en buena medida, Prometeo remeda ese estilo moroso, esmerado y detallado en la prolijidad de descripciones.

Asimismo, es frecuente la alusión a los nombres de los vientos -Euros, Zéfiros, Notos y Bóreas - y a personajes de gran relevancia en el universo homérico, tales como Hermes, el mensajero de los dioses, o Tiresias, el célebre adivino ciego de la ciudad de Tebas. En la narración de Pérez de Ayala se distinguen lugares reconocibles de la fábula homérica: la tierra de los Lotófagos, la morada de Circe, el descenso o catábasis al Hades o reino de los muertos, las vacas de Helios, Scila y Caribdis, los amores con la ninfa Calipso y llegada al país de los Feacios con Nausikaa.

\section{El sentido de la risa desde la tradición}

Partiendo del fenómeno de la parodia, se puede analizar el sentido de lo cómico en las obras de Ramón Pérez de Ayala y Antonio Gala. Lo cómico, desde el punto de vista del espíritu ortodoxo, adviene como resultado de una caída, deudora a su vez de la degradación física o moral del ethos del héroe. En las palabras prologales que Antonio Gala escribe al inicio de ¿Por qué corres, Ulises? 
categoriza genéricamente su pieza teatral en términos de comedia, por tanto, está apuntando hacia el poder risible que en ella se atisba. Sin embargo, ya en el epílogo de la misma obra podemos leer:

¿"Por qué corres, Ulises"? es una tragedia tan frecuente que ha dejado de serlo y se ha vuelto costumbre [...] No requiere un desarrollo ni un final sangrientos: las heridas más hondas son las que menos sangran. Verificar que todo hombre es, en definitiva, un pobre hombre y que toda mujer, sea como sea, no es más que una mujer, puede dar risa. Quizá el mejor espectador sea aquel que, mientras se sonríe, acierte a comprenderlo.

(Gala, 1975, p. 98)

Igualmente sutil es el juego que Ramón Pérez de Ayala establece con el atento lector en Prometeo. Como se ha comprobado a propósito de los estilemas expresivos, la recreación del mito de Ulises deviene más palpable en virtud de la cualidad ostensible de las marcas de estilo, que reproducen los rasgos fisonómicos del texto homérico, como un Narciso mirándose en el reflejo de las aguas para hallar su Calibán.

Tanto Prometeo como ¿Por qué corres, Ulises? se pueden leer en clave lúdico-paródica, en tanto desmitificación (Harris, 1986) del héroe perfilado por Homero, el primer poeta de Occidente. Sin embargo, detener la atención en esa lectura sería insuficiente, por cuanto la risa entraña también un poder subversivo y esconde una suerte de rebelión contra la autoridad o la moral establecida. Por esta razón, la hermenéutica de estas obras se realiza de un modo integral si a esa caída que provoca la risa, insertamos un espíritu crítico al formular la pregunta: ¿Qué nos estarán queriendo decir Ramón Pérez de Ayala en 1916 y Antonio Gala en 1975? ¿Pretenden reírse de la figura de Ulises o más bien eligen esa figura para realizar una acerba crítica social, ironía y descreída, incentivando el espíritu pensante de cualquier desocupado lector? A mi juicio, la clave interpretativa de ambas obras se fija en el punto medio en que el poder risible tras la lectura deviene subversión. Por eso, estos textos paródicos se vinculan de manera estrecha con el signo anti-alazónico ${ }^{24}$, en tanto distancia ideológica que el lector ha de mantener, siempre en un juego hermenéutico en el que el texto base A (hipotexto: la Odisea), se encuentra en un nivel más elevado que el texto $B$ (hipertexto). Entre el texto paródico y el parodiado media una distancia considerable. Mientras que la Odisea homérica se considera el texto canónico sobre el que se han dibujado el rostro de la tradición, el texto paródico es vástago de la pátina del tiempo, acorde con su época.

Uno de los defectos a los que la modernidad nos ha llevado radica en desideologizar los contextos epistemológicos, a pensar que el significado de los textos y, en último término, su sentido es inocente. Si bien Genette (1982, p. 36) define la parodia como la "transformación lúdica" que un texto realiza respecto de otro texto mediante una "práctica hipertextual", habría que incluir un componente de subversión ideológica del texto base.

\section{Hacia una conclusión. Siempre Homero. La Odisea a través de los siglos}

Si en la clasicidad el mito revelaba las verdades eternas sobre el hombre, en el mundo moderno, sin embargo, la mitología clásica se tiñe de un sentimiento de nostalgia inherente a las versiones literarias del siglo XX sobre los mitos (García Gual, 1997). La fe en el mundo parece haberse perdido $y$, ante tal hecatombe, el escritor no puede sino cantar a lo que nunca será. Ítaca es también una meta imposible en el relato de Pérez de Ayala y en la pieza teatral de Gala. Mediante la ironía, el autor puede soñar lo que no fue, distanciándose de su realidad para no herirse ante la

24 Véase el sentido bíblico de alazoneia, palabra de gran fortuna a lo largo de la historia desde la Antigüedad: en Moralia de Plutarco, la Ética a Nicómaco de Aristóteles o la Ciropedia de Jenofonte. Alazoneia apunta a la verborrea del fanfarrón que se atribuye más cualidades de las que en realidad posee. Volviendo el argumento por pasiva, la ironía y la parodia emergen como mecanismos anti-alazónicos que mantienen en guardia al lector. 
crueldad de las acciones humanas. Puede, asimismo, dudar de la verdad, porque como escribió Nietzsche:

¿Qué es la verdad? Un ejército móvil de metáforas, metonimias, antropomorfismo, en una palabra, una suma de relaciones humanas que han sido realzadas, extrapoladas, adornadas, poéticamente y retóricamente y que, después de un prolongado uso, a un pueblo le parecen fijas, canónicas, obligatorias: las verdades son las ilusiones de los que se han olvidado de que lo son ${ }^{25}$.

Pese a la falta de verdad en el mundo moderno, en esta línea interpretativa el sentido de búsqueda no se pierde, porque la vida se concibe como camino que nos permite salir del sentido circular de la historia. Sin embargo, aunque el Ulises de Ayala y Gala camine en línea recta y siga un itinerario trazado en pos de la superación, no hay otra meta más que la conciencia de que el hombre debe resignarse. Ya no existe la pasión sin límites ni el amor desaforado. Ya no hay Penélope a la que cantar. Penélope vive como imagen soñada en ¿Por qué corres, Ulises? y en Prometeo aflora como figura alegórica de la realización de los ideales humanos. Es cierto que las historias mitológicas surgidas en estas dos versiones de Ulises en el siglo XX desprenden un mensaje desesperanzador. Del nostos solo queda el dolor y de ahí proviene etimológicamente la palabra nostalgia.

La Odisea homérica es una epopeya, género acogido por Aristóteles en su Poética, pero los temas literarios están bajo el signo de Proteo y un tema puede ser expresado de modo cambiante y multiforme. Es muy probable que ante los ojos de un lector del siglo XXI el tema del astuto Odiseo, del errabundo viajero y peregrino por tierras ignotas apenas tenga valor. Por eso, los temas deben evolucionar y avanzar a lo largo del tiempo (Yélamos, 1992), porque su formulación literaria se irá actualizando de acuerdo con la tensión entre lo uno y lo diverso (Guillén, 2005). Si bien es cierto que el personaje de Odiseo, emblema del peregrino errante, es un motivo que ha perdurado como fenómeno cultural, que es un tema de larga duración histórica. La novela emerge entonces como estertor del mito, que se hubiera perdido de no ser por la fuerza del logos escrito, según el debate surgido desde el emblemático Fedro de Platón. Pérez de Ayala recupera el mito primitivo, lo convierte en mito literario de acuerdo con los intereses socioculturales de la España del siglo XX. Hablaríamos, así, de reinterpretaciones agregadas al mito original, donde el mito en su sentido primario se ve adornado por la ficción novelística. De hecho, en Prometeo, el lector se siente entre la Grecia de Homero y la España del siglo XX.

La certeza de que un mismo tema se pueda verter bajo moldes muy diversos (los géneros literarios) -el Ulysses de Joyce, el poema Odiseo de Katzantzakis o Ítaca de Kavafis_, incide en la pervivencia de estos mitos literarios (Gallardo López, 1991; Ragué Arias, 1992). Mediante la escritura de Prometeo, Pérez de Ayala reinterpreta el mito originario de Ulises. Con todo, tanto Prometeo como ¿Por qué corres, Ulises? tocan con su osada mano el corazón mismo del ensayo La tradición y el talento individual (1919) de T. S. Eliot, pues el poeta vive "en lo que no es meramente el presente, sino el momento presente del pasado, consciente no de lo que ha muerto, sino de lo que sigue vivo", volviendo la mirada hacia nuestra tradición literaria, desde Homero, pasando por Tennyson, hasta Kavafis, Pérez de Ayala o Gala. De esta manera, podemos responder a la pregunta de Italo Calvino con que se intitula su obra ¿Por qué leer los clásicos? Es gustosa la lectura de los clásicos porque leerlos significa estar descubriendo siempre un nuevo horizonte estético, cultural y artístico en el que reescribir la historia del pensamiento occidental. Como señala Umberto Eco en sus Apostillas a El nombre de la rosa, leer y releer implica apreciar "los ecos de la intertextualidad", pues "los libros siempre hablan de otros libros y cada historia cuenta una historia que ya se ha contado. Lo sabía Homero, lo sabía Ariosto, para no hablar de Rabelais o de Cervantes" (Eco, 2009, p. 745-746).

Como primer poeta de la literatura en occidente, Homero forma parte de nuestra tradición,

25 Véase F. Nietzsche, Sobre verdad y mentira en sentido extramoral, I, VII. 
porque el ciego de Quíos ha logrado crear héroes literarios que se elevan a la categoría de arquetipos. En concreto, Ulises u Odiseo se alza como alegoría de la búsqueda en el siglo XX, como figura modelable que no perece con el paso del tiempo. Al contrario, el tiempo imprime en su rostro una nueva luz y una nueva mirada en sus ojos. El mito de Odiseo perpetúa su vigencia en la literatura del siglo XX, quizá para revelar a Homero y para reescribir una historia susceptible de nuevas adaptaciones y versiones. En definitiva, todo ser humano aguarda en su interior a un Ulises particular $^{26}$.

En síntesis, la ironía y la parodia afloran como técnicas subversivas del arte literario en que impera la bivocalidad, es decir, la pugna perpetua entre dos voces. Sin embargo, frente a la parodia donde el texto A (hipotexto) se encuentra explícito, en la ironía ese texto base sobre el cual se apoya el texto B (hipertexto), pierde su carácter de explicitud. Requiere, por lo tanto, un mayor grado de agudeza en el lector. He ahí su signo anti-alazónico. Por esta razón, mediante la ironía el autor y el lector bailan una danza intelectual, con el ánimo de desentrañar los significados latentes en la obra literaria. De esta manera, se corona lo que Barthes denominaba "el placer del texto", porque "una obra es "eterna" no porque imponga un sentido único a hombres diferentes, sino porque sugiere sentidos diferentes a un hombre único, que habla siempre la misma lengua simbólica a través de tiempos múltiples" (Barthes, 2004, p. 53). Ramón Pérez de Ayala y Antonio Gala sugieren esos sentidos diferentes del texto, al tiempo que bailan con Homero esa danza intelectual —en su sentido etimológico intus-legere o leer por dentro-y, todavía hoy, siguen suscitando en el lector el vivo encanto de la sabiduría homérica.

\section{Bibliografía}

Auerbach, E. (1983). Mímesis. La representación de la realidad en la literatura occidental. México: Fondo de Cultura Económica.

Bajtin, M. (1989). Teoría y estética de la novela, Madrid: Taurus.

Ballart, P. (1994). Eironeia. La figuración irónica en el discurso literario moderno. Barcelona: Quadernus Crema.

Barthes, R. (1968). El efecto de realidad. Communications, 11. París: Escuela Práctica de Altos Estudios.

Barthes, R. (1997). Roland Barthes por Roland Barthes, 2. ${ }^{a}$ ed., Caracas: Monte Ávila Editores.

Barthes, R. (2004). Crítica y verdad. Buenos Aires: Siglo XXI.

Benjamin, W. (1991). El narrador. Madrid: Taurus.

Blumenberg, H. (2003). Trabajo sobre el mito. Barcelona: Paidós.

Boitani, P. (1992). L'ombra di Ulisse: figure di un mito. Bolonia: III Mulino.

Brommer, F. (1983). Odysseus. Die Taten und Leiden des Helden in antiker Kunst und Literatur. Darmstadt.

Calvino, I. (1993). ¿Por qué leer los clásicos? Barcelona: Círculo de Lectores.

Calvo Martínez, J. L. (1991). La figura de Ulises en la literatura española. En López Férez, J. A. (ed.), La épica griega y su influencia en la literatura española. (Aspectos literarios, sociales y educativos) (pp. 33-358). Madrid: Ediciones Clásicas.

Cazorla, H. (1986). El retorno de Ulises: dos enfoques contemporáneos del mito en el teatro de Buero Vallejo y Antonio Gala. Hispanófila 87, 43-51.

Curtius, E. R. (1995). Literatura Europea y Edad Media Latina. Madrid: Fondo de Cultura Económica. Dällenbach, L. (1977). Le récit spéculaire. Essai sur la mise en abyme, París: Seuil.

26 Mediante las palabras de Nausica, el motivo de la odisea como viajero o periplo se eleva a categoría universal, en una experiencia compartida por todas las generaciones desde Homero: "NAUSICA (Yendo hacia él, acariciándolo.) Todos tenemos nuestra odisea, Ulises. la odisea no es ir de isla en isla, camino de la nuestra, sino de persona en persona, camino de nosotros... Si, en el fondo, tú sabes que siempre se acaba en donde se empezó, ¿por qué corres, Ulises?" (Gala, 1975, p. 81). 
García Gual, C. (1997). La mitología: Interpretaciones del pensamiento mítico, 3. ${ }^{a}$ ed. Madrid: Montesinos.

Eco, U. (2009). El nombre de la rosa (2.. ed.). Barcelona: Debolsillo.

Eliade, M. (1998). Lo sagrado y lo profano. Barcelona: Paidós.

Eliot, T. S. (1986). Tradition and Individual Talent. The sacred wood. Essays on Poetry and Criticism. London: Methuen.

Felson-Rubin, N. (1994). Regarding Penelope. From character to poetics. Princeton: Princeton University Press.

Gala, A. (1975). ¿Por qué corres, Ulises? Madrid: Colección Teatral de Autores Españoles.

Gallardo, M. D. (1991). Pervivencia del mito en tres autores actuales. Cuadernos de Filología Clásica (Estudios Latinos), 1, 241-258.

García Romero, F. (1983). El mito de Ulises en el teatro español del siglo XX. Cuadernos de Filología Clásica: Estudios griegos e indoeuropeos, 18, 361-382.

García Romero, F. (1997). Sobre Penélope de Domingo Miras. Epos, 13, 55-75.

García Romero, F. (1999). Observaciones sobre el tratamiento del mito de Ulises en el teatro español contemporáneo. Analecta Malacitana, XX.2, 513-526.

García Romero, F. (2002). Pervivencia de Penélope, En Morenilla Talens, C. y De Martino, F. (coords.), El perfil de les ombres. El teatre clàssic al marc de la cultura grega i la seua pervivència dins la cultura occidental (pp. 187-204). V. Levanti Editori.

Genette, G. (1989). Palimpsestos. La literatura en segundo grado. Madrid: Taurus.

Gómez, P. (1990). Parodia y parodiar en la Grecia antigua. Estudios Clásicos, 98, 7-26.

Gómez Espelosín, F. J. (2000). El descubrimiento del mundo. Geografía y viajeros en la Antigua Grecia. Madrid: Akal.

Guillén, C. (2005). Entre lo uno y lo diverso: Introducción a la literatura comparada (ayer y hoy). Barcelona: Tusquets.

Harris, C. (1986). El teatro de Antonio Gala. Toledo: Zocodover.

Joyce, J. (1980). Retrato del artista adolescente. Barcelona: Argos Vergara.

Katz, M. A. (1991). Penelope's renown. Meaning and indeterminacy in the Odyssey. Princeton: Princeton University Press.

Kristeva, J. (1997). Bajtin, la palabra, el diálogo y la novela. En Navarro, D. (selecc. y trad.), Intertextualité (pp. 111-132). La Habana: UNEAC, Casa de las Américas.

Landero, L. (1996). Quince líneas. Relatos hiperbreves. Barcelona: Tusquets.

Lasso de la Vega, J. (1989). La presencia del mito griego en nuestro tiempo. En Homenaje a Santiago Montero. Anejos de Gerión II (pp. 99-114). Madrid.

Lens Tuero, J. y Campos Daroca, J. (2000). Utopías del mundo antiguo, Antología de textos. Madrid: Alianza.

López Férez, J. A. (2009). Presencia de la Odisea en ¿Por qué corres, Ulises? de Antonio Gala. Fortunatae, 20, 49-70.

López López, A. (2000). El arquetipo de Penélope en el teatro: Plauto, Buero Vallejo e Itziar Pascual. En Andresen K., Bañuls J. V. y De Martino, F. (eds.), La dualitat en el teatre (pp. 207-225). Bari.

Mactoux, M. M. (1975). Pénélope, légende et mythe. París: Magalhães.

Martínez Moreno, I. (1994). Antonio Gala: El Paraíso perdido. Madrid: Consejo Superior de Investigaciones Científicas.

Milton, J. (1979). El Paraíso Perdido. Barcelona: Petronio.

Morano, C. (1982). El resurgir de lo mítico en la literatura contemporánea: diversos procedimientos de acceso al mito. Faventia, 4, 77-93.

Moya, F. (2009). Sastre y Gala: dos posturas ante el mito. En López Férez J. A. (ed.). Mitos en la literatura española e hispanoamericana del siglo XX (pp. 527-544). Madrid: Ediciones Clásicas.

Navarro, J. L. (1993). De Homero a Gala: ¿Por qué corres, Ulises?. Aula Abierta, 9, 21-27.

Paulino Ayuso, J. (1994). Ulises en el teatro español contemporáneo. Una revisión panorámica. Anales de la Literatura Española Contemporánea, 19, 327-342. 
Pérez de Ayala, R. (1998). Obras completas. Madrid: Fundación José Antonio de Castro, III. Perpinyá, N. (2008). Las criptas de la crítica. Veinte interpretaciones de la Odisea. Madrid: Gredos. Pozuelo Yvancos, J. M. (2007). Desafíos de la teoría: literatura y géneros. Mérida: El otro, el mismo. Ragué Arias, M. J. (1992). Lo que fue Troya. Los mitos griegos en el teatro español actual. Madrid: Asociación de Autores de Teatro.

Robertson, V. (1992). Antonio Gala's '¿Por qué corres, Ulises?'. Form in search of content. Anales de la Literatura Española Contemporánea, 17, 221-228.

Rodríguez Adrados, F. (1962). El héroe trágico y el héroe platónico. Madrid: Taurus.

Rogers, E. S. (1984). Myth, man and exile in 'El retorno de Ulises' and '¿Por qué corres, Ulises? Anales de la Literatura Española Contemporánea, 9, 117-129.

Rohde, E. (1983). Psique. La idea del alma y la inmortalidad entre los griegos. México: Fondo de Cultura Económica.

Stanford, W. B. (2013). El tema de Ulises. Madrid: Clásicos Dykinson.

Tomachesvski, B. (1982[1928]): Teoría de la literatura. Madrid: Akal.

Trousson, Raymond (1976). Le thème de Prométhée dans la littérature européenne. inebra: Librairie Droz.

Yélamos, Gonzalo (1992). Actualidad de los mitos clásicos. En Guzmán, A., Gómez Espelosín F. J. y Gómez Pantoja, J. (eds.). Aspectos modernos de la Antigüedad y su aprovechamiento didáctico (pp. 330-332). Madrid: Ediciones Clásicas.

\section{Fuentes}

Aristóteles, Retórica. Madrid: Alianza. 8. a reimpresión. 2009. [Introducción, traducción y notas de Alberto Bernabé].

Aristóteles, Poética. Madrid: Alianza. 2010. [Nueva reimpresión, traducción, introducción y notas de Alicia Villar Lecumberri].

Hesíodo, Teogonía. Madrid: Alianza. 1993. [Traducción española de Adelaida y María de los Ángeles Martín Sánchez].

Homero, Ilíada. $2^{a}$ ed. Barcelona: Planeta. 1973. [Introducción y notas de José Alsina]. [Traducción en verso de Fernando Gutiérrez].

Homero, Odisea. $2^{a}$ ed. Barcelona: Planeta. 1973. [Introducción y notas de José Alsina]. [Traducción en verso de Fernando Gutiérrez].

Platón, República. Madrid: Gredos. 2008. [Introducción, traducción y notas de Conrado Eggers Lan].

Luciano Samosata. Relatos verídicos. Madrid: Gredos. 1996. [Traducción española de Andrés Espinosa Alarcón].

Virgilio, Eneida. $10^{\text {a }}$ ed. Madrid: Cátedra. 2006. [Traducción española de Aurelio Espinosa]. 



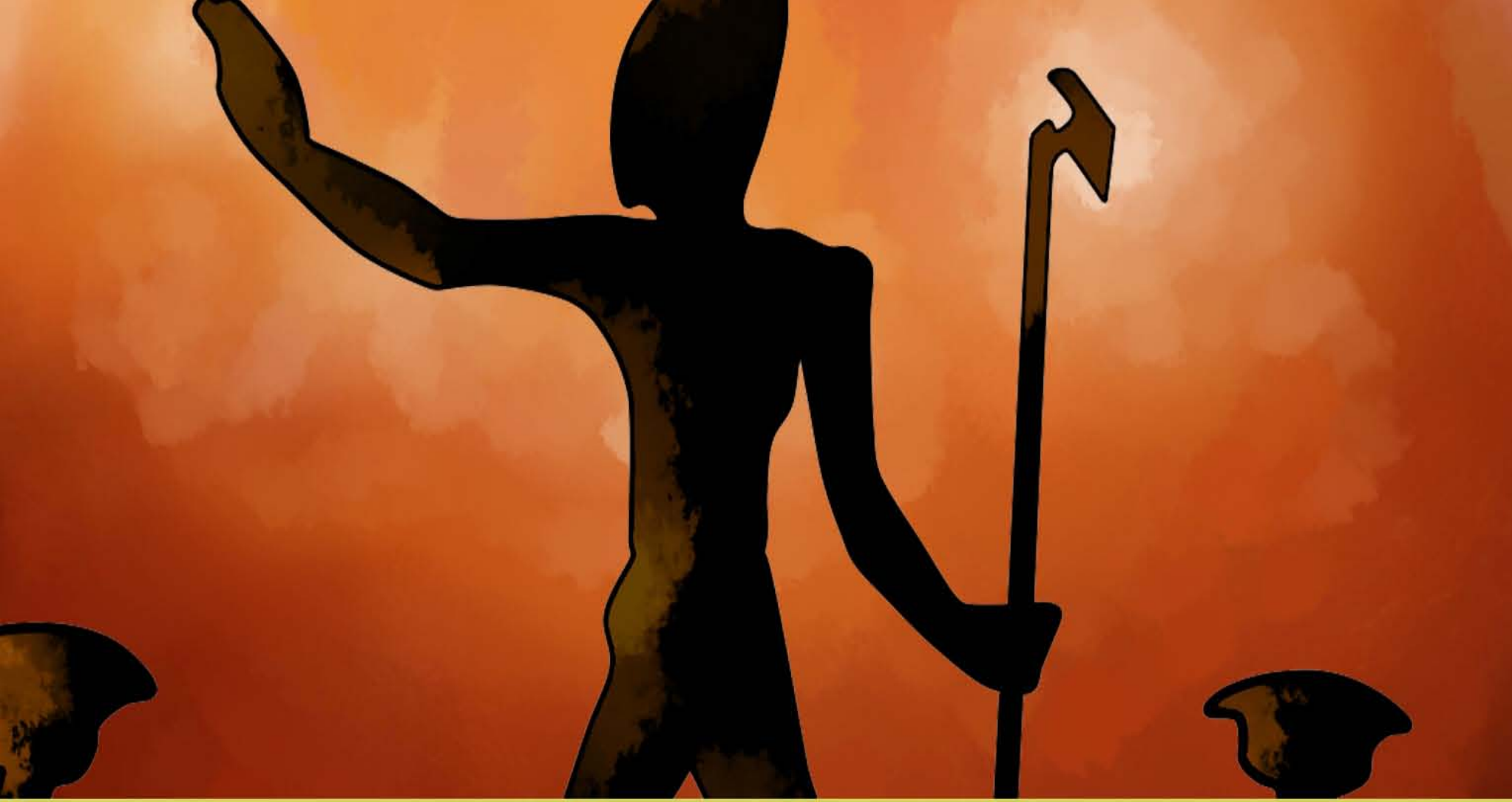

